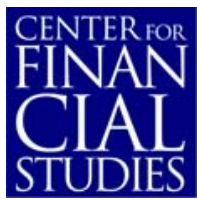

No. $2011 / 21$

Financial Literacy, Retirement Planning, and Household Wealth

\author{
Maarten van Rooij, Annamaria Lusardi, \\ and Rob Alessie
}




\section{Center for Financial Studies}

The Center for Financial Studies is a nonprofit research organization, supported by an association of more than 120 banks, insurance companies, industrial corporations and public institutions. Established in 1968 and closely affiliated with the University of Frankfurt, it provides a strong link between the financial community and academia.

The CFS Working Paper Series presents the result of scientific research on selected topics in the field of money, banking and finance. The authors were either participants in the Center's Research Fellow Program or members of one of the Center's Research Projects.

If you would like to know more about the Center for Financial Studies, please let us know of your interest.

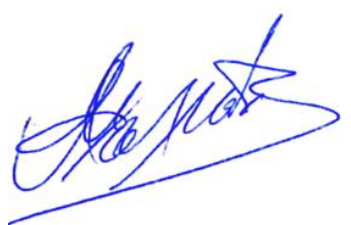

Prof. Michalis Haliassos, Ph.D.
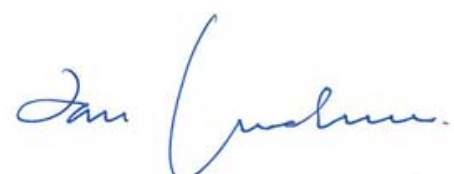

Prof. Dr. Jan Pieter Krahnen

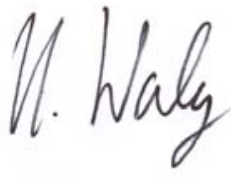

Prof. Dr. Uwe Walz 


\title{
Financial Literacy, Retirement Planning, and Household Wealth*
}

\author{
Maarten van Rooij ${ }^{1}$, Annamaria Lusardi ${ }^{2}$, \\ and Rob Alessie ${ }^{3}$
}

\section{August 2011}

\begin{abstract}
:
There is ample empirical evidence documenting widespread financial illiteracy and limited pension knowledge. At the same time, the distribution of wealth is widely dispersed and many workers arrive on the verge of retirement with few or no personal assets. In this paper, we investigate the relationship between financial literacy and household net worth, relying on comprehensive measures of financial knowledge designed for a special module of the DNB (De Nederlandsche Bank) Household Survey. Our findings provide evidence of a strong positive association between financial literacy and net worth, even after controlling for many determinants of wealth. Moreover, we discuss two channels through which financial literacy might facilitate wealth accumulation. First, financial knowledge increases the likelihood of investing in the stock market, allowing individuals to benefit from the equity premium. Second, financial literacy is positively related to retirement planning, and the development of a savings plan has been shown to boost wealth. Overall, financial literacy, both directly and indirectly, is found to have a strong link to household wealth.
\end{abstract}

JEL Classification: D91, D12, J26

Keywords: Financial Education, Savings and Wealth Accumulation, Retirement Preparation, Knowledge of Finance and Economics, Overconfidence, Stock Market Participation

\footnotetext{
* We thank Carol Bertaut, Johannes Binswanger, Thomas Crossley, Michael Haliassos, Lex Hoogduin, Peter Schotman, Federica Teppa, Joachim Winter and Peter van Els for their advice and comments, and Audrey Brown for excellent editorial assistance. We also thank the staff of CentERdata and, in particular, Corrie Vis for their assistance with the survey and the field work. The views expressed in this paper are those of the authors and do not necessarily reflect the views of De Nederlandsche Bank.

1 De Nederlandsche Bank and Netspar, Economics \& Research Division, Contact Address: De Nederlandsche Bank, P.O. Box 98, 1000 AB, Amsterdam, The Netherlands. E-mail: M.C.J.van.Rooij@dnb.nl

2 The George Washington University School of Business, 2201 G Street, NW, Washington, DC 20052, USA. E-mail: alusardi@gwu.edu

3 School of Economics and Business, University of Groningen, P.O. Box 800, 9700 AV, Groningen, The Netherlands.

E-mail: R.J.M.Alessie@rug.nl
} 


\section{Introduction}

Households hold very different amounts of wealth. Heterogeneity in lifetime earnings, the willingness to leave bequests, motives for precautionary and other savings, and cross sectional differences in time preferences, expectations about the future, health, longevity, inheritances, and income shocks all contribute to the dispersion in wealth holdings and have been researched extensively. ${ }^{1}$ The relationship between wealth accumulation and financial literacy has received much less attention, mainly because of a dearth of information of financial knowledge levels in the population. Recently, however, there has been burgeoning research on the measurement of financial literacy and its effects on household behaviour (e.g., Van Rooij, Lusardi and Alessie, 2011a; Lusardi and Mitchell, 2007a, 2008, 2009, 2011a; Agnew, Szykman, Utkus and Young, 2007; Kimball and Shumway, 2006, among others). In this paper, we report findings from an extensive set of questions designed to measure basic and advanced financial knowledge and study the relationship between financial knowledge and household wealth.

The relationship between financial literacy and household behaviour is important, as individuals are increasingly being asked to take on responsibility for their financial well-being and their retirement preparation. However, researchers have found that individuals do not save enough for retirement (see, e.g., Bernheim, Skinner and Weinberg, 2001). ${ }^{2}$ There is an obvious policy interest in understanding whether financial education affects saving behaviour and what types of educational programs are most effective. The empirical evidence of the effect of financial education and the provision of information on saving behaviour is mixed (Lusardi, 2004). Moreover, even if studies find a significant impact of financial education on savings, we usually do not have much information on the channel underlying this effect. Studies on the impact of retirement seminars, for example, are typically not able to disentangle the consequences of an increase in financial knowledge, if any, from behavioural effects due to the provision of information-retirement seminars being part of a more comprehensive initiative to increase financial awareness — or the importance of peer effects in raising saving rates (Duflo and Saez, 2003). In our work, we isolate the effect of financial skills, investigate whether financial literacy has an impact on wealth accumulation, and

\footnotetext{
${ }^{1}$ See the references in the next section.

${ }^{2}$ Using data from the Health and Retirement Study, Scholz, Seshadri and Khitatrakun (2006), however, find that the overwhelming majority of US households do not "undersave" for retirement. This conclusion is based on a comparison of actual wealth levels with "optimal” wealth levels. The optimal wealth levels are derived from an expanded life cycle model that incorporates consumption by children, uncertain lifetimes, uninsurable earnings and medical expenses, progressive taxation, government transfers, and pension and social security benefits.
} 
examine what underlying channels are at work for financial literacy to have an effect on wealth.

The main contributions of this paper are the following: First, we provide evidence of a positive association between financial literacy and wealth holdings after controlling for other determinants of wealth, such as income, age, education, family composition, risk tolerance, patience, and attitudes toward saving. Such a positive association cannot be immediately interpreted as a causal effect because of omitted variables and/or simultaneity bias and because of measurement error problems. We use instrumental variables estimation to assess the causal effect of financial literacy on wealth accumulation. Finding suitable instruments is a difficult task and we do not claim that our instruments irrefutably establish a causal effect of financial literacy on household wealth.

The second contribution of the paper is that we identify and highlight two channels through which financial literacy might facilitate wealth accumulation. First, a high level of financial knowledge lowers the costs of gathering and processing information and reduces barriers to investing in the stock market (Haliassos and Bertaut, 1995; Vissing-Jorgenson, 2004). Individuals with high financial literacy are found to be more likely to invest in the stock market (Van Rooij, Lusardi and Alessie, 2011a). A reason for the positive correlation between literacy and wealth accumulation might be that knowledgeable individuals take advantage of the equity premium on stock investments. Second, financial literacy is found to be positively associated with retirement planning behaviour (Lusardi, 1999; Lusardi and Mitchell, 2007a, 2009, 2011b; Ameriks, Caplin and Leahy, 2003), and our empirical results suggest that respondents with more confidence in their financial knowledge have a higher propensity to plan. From this, we can intuit that a high level of financial knowledge reduces planning costs, i.e., reduces the economic and psychological barriers to acquiring information, doing calculations, and developing a plan. Our data show that once households calculate their savings needs after retirement, they often follow through with setting up a retirement plan and are successful in sticking to their plan (see also Lusardi and Mitchell, 2011b).

This paper is organised as follows. In Section 2, we review the current literature on both wealth accumulation and financial literacy. In Section 3, we present data and descriptive statistics and explain how our measures of basic and advanced financial literacy are constructed. In Section 4, we analyse the relationship between wealth and financial literacy, after accounting for many determinants of wealth holdings. In Section 5, we present several extensions to our regression analyses and discuss the robustness of our results. In Section 6, we consider the two channels through which financial knowledge may exert an effect on 
wealth accumulation: stock market participation and retirement planning activities. In addition, we examine the economic relevance of the financial literacy-wealth relationship. In Section 7, we conclude and discuss policy implications.

\section{Literature Review}

The simplest version of the life cycle consumption model without bequests and uncertainty posits that households accumulate savings during their working careers up to their retirement, and decumulate wealth thereafter (Modigliani and Brumberg, 1954). This type of saving behaviour enables households to smooth their marginal utility of consumption over the life cycle. However, there are many reasons why household consumption and wealth follow patterns different than that predicted by the life cycle model, and the standard model can be easily adjusted to account for these reasons (for an overview, see Browning and Lusardi, 1996). For example, studies have highlighted the role of precautionary saving motives (Hubbard, Skinner and Zeldes, 1995), longevity and bequests (Hurd, 1989), different economic opportunities across cohorts (Kapteyn, Alessie and Lusardi, 2005), self-control problems (Laibson, 1997; Benartzi and Thaler, 2004; Ameriks, Caplin, Leahy and Tyler, 2007), unexpected events (Venti and Wise, 1998; Lusardi, 2003), and health (Rosen and Wu, 2004). None of these studies have focused on the role of financial literacy in accumulating wealth; however, more financially sophisticated individuals may face lower barriers to gathering and processing information and thus be better equipped to both accumulate and manage their savings.

Somewhat related to the subject of our study is the work by Chan and Stevens (2008) who document that households base pension and retirement saving decisions upon limited and sometimes incorrect pension knowledge. ${ }^{3}$ One may argue whether financial literacy affects knowledge of pensions and Social Security benefits. Using data from a sample of older US individuals, Gustman, Steinmeier and Tabatabai (2010) do not find any relationship between basic cognitive skills (numeracy) and knowledge of retirement plan characteristics and Social Security. While there is a positive relationship between pension wealth and knowledge, Gustman, Steinmeier and Tabatabai (2010) argue that the causality is more likely to run from pension wealth to pension knowledge than the other way around, and that the positive

\footnotetext{
${ }^{3}$ Many authors have documented that households are rather ill-informed about their Social Security benefits and company pensions. See Gustman, Steinmeier, and Tabatabai (2008) and Van Els, Van den End, and Van Rooij (2004) for evidence for the US and the Netherlands, respectively.
} 
numeracy-wealth relationship should not be taken as evidence that increasing cognitive skills and numeracy will increase the wealth of households as they enter into retirement.

Bernheim $(1995,1998)$ was among the first to note that policymakers and researchers might have overlooked the importance of financial literacy to explain savings and differences in saving behaviour. Since then many studies have emphasised the role of financial knowledge but, in the absence of specific literacy measures, resort to crude proxies (Calvet, Campbell and Sodini, 2007; Vissing-Jorgenson, 2004). The disadvantage of these proxies is that there is no way to disentangle the effect of financial literacy from the effect of the proxy variable. For example, by using education as a measure of financial literacy, one is not able to separate the independent effect of financial knowledge from the impact of the education level, per se; in many regressions, education also serves as a proxy for lifetime income.

In the past few years researchers have increased their efforts to develop specific measures of financial knowledge and have also investigated the relationship between financial literacy and financial decision-making. Hilgert, Hogarth and Beverly (2003) developed a set of true/false questions to measure financial knowledge and explored the relationship between financial knowledge and money management. Lusardi and Mitchell (2011b) pioneered a module to measure financial literacy that was part of the 2004 Health and Retirement Study (HRS). ${ }^{4}$ They showed there is strong positive association between financial literacy and retirement planning. More recently, Van Rooij, Lusardi and Alessie (2011a), Yoong (2011) and Christelis, Jappelli and Padula (2010) showed that there is a positive relationship between the decision to invest in stocks and specific measures of financial literacy and cognitive ability.

An increasing number of studies document the prevalence of financial mistakes. Agarwal, Driscoll, Gabaix and Laibson (2009) provide evidence of financial mistakes in the loan market, with many households paying excessive fees or too-high interest rates on credit card debt, home equity loans and mortgages (see also Moore, 2003). Calvet, Campbell and Sodini (2007) show that in Sweden-a country that is often considered to have well-informed investors-many households hold underdiversified portfolios or do not participate in financial markets at all. Several authors have also stressed that the welfare costs of financial mistakes are not negligible (Campbell, 2006; Calvet, Campbell and Sodini, 2007; Cocco, Gomes and Maenhout, 2005).

\footnotetext{
${ }^{4}$ The questions designed for the US Health and Retirement Study have now been used in many other countries. See Lusardi and Mitchell for an overview (2011c).
} 
This prevalence of financial mistakes might not come as a surprise, given the evidence of limited financial literacy among households. This evidence is robust in different settings and across different countries-many of which have responded by setting up financial education programs (OECD, 2005; Lusardi and Mitchell, 2011a). While the wide variation in financial literacy initiatives offers opportunity to better understand effective design and implementation of financial education programs, evaluations have, so far, been limited (Smith and Stewart, 2008).

The impact of financial education on saving behaviour has been investigated, mostly in the context of retirement seminars offered by US firms. Bernheim and Garrett (2003), Lusardi (2004) and Clark and D’Ambrosio (2008) have documented positive effects of retirement seminars in the workplace. Overall, however, the evidence is mixed, as other studies have not been able to come up with significant, lasting effects (Duflo and Saez, 2003, 2004). Moreover, as attendance at retirement seminars is voluntary, it is possible that participants are from a select group that is already more intrinsically motivated to remedy insufficient savings. In addition, any beneficial effect of retirement seminars could be the direct result of the provision of information on the need for retirement savings rather than of an increase in financial literacy. This is especially likely as retirement seminars typically take a few hours at most. The impact of financial education on savings in these studies might, for example, work more indirectly through an effect on individual characteristics and the appetite for saving. Bernheim, Garrett and Maki (2001) found positive effects of financial education during high school on long-term savings, but these findings have been contradicted by more recent work (Cole and Shastry, 2008).

In this paper, we do not evaluate financial education programs but focus directly on the role of financial knowledge on wealth accumulation, and we disentangle these effects from other personal traits related to a propensity to save, including risk tolerance and patience.

\section{Data}

We have devised a special module for the annual DNB (De Nederlandsche Bank) Household Survey (DHS), which includes a set of questions on financial knowledge as well as a section on retirement planning activities. The questions have been answered by the household panel run by CentERdata, a survey agency at Tilburg University specialising in internet surveys. It is important to note that even though the Netherlands has an internet penetration of about $80 \%$, the selection of panel members is not dependent on their use of and 
access to the internet. Households without a computer or an internet connection are provided with the necessary equipment (e.g., a set-top box that enables participation through their television). Attrition is dealt with by biannual refreshment samples that are drawn so as to keep the panel representative of the Dutch population of 16 years of age and older (individuals in hospitals, specialised care institutions or prisons are not included). ${ }^{5}$

Our questionnaire was administered to individuals who are in charge of their household's finances. It was fielded from 23 September to 27 September 2005 and repeated a week thereafter for those households that had not yet responded. The response rate was $74.4 \%$ (1508 out of 2028 households). The DHS contains a lot of information on income and work, health, household debt and assets, and an extensive set of psychological questions on attitudes with respect to saving and portfolio investments. We merge our module on financial literacy with the 2005 data from the questionnaire on net worth. Since wealth regressions might be sensitive to outliers, we trim the net worth variable and exclude the top and bottom $1 \%$ of the net worth distribution.

Our final sample consists of 1091 households. Table A1 reports summary statistics of some important background variables for the whole sample and the final sample (see appendix A). The average age of respondents in the whole sample is 50.8 (ranging from 22 to 90 years); $51.5 \%$ of respondents are male; $56.8 \%$ are married or living with a partner; and $18.4 \%$ are retired. Comparison of the characteristics for the whole sample and the final sample shows that elderly respondents report their asset and debt position more frequently, but overall the composition of the sample remains fairly similar. Table A2 reports the median, mean and standard deviation of household net worth, which includes all types of private savings and investment accounts, housing wealth, other real estate, and durable goods, net of mortgages and other financial debt. It is clear that the wealth distribution is wide even after trimming the top and bottom $1 \%$ of the distribution.

\subsection{The measurement of literacy ${ }^{6}$}

The module that we have added to the DHS contains two sets of questions to assess financial literacy. These questions were mostly designed using similar modules from the US

\footnotetext{
${ }^{5}$ We use household weights to calculate the statistics reported in this paper to ensure representativeness of the population.

${ }^{6}$ See Van Rooij, Lusardi and Alessie (2011a) for a detailed description of the measurement of financial literacy and its relationship to demographics.
} 
Health and Retirement Survey (HRS) and a variety of other surveys on financial literacy, but a few questions are unique to our module. ${ }^{7}$

The first set of questions relates to basic financial literacy. Appendix B reports the exact wording of the questions, which measure ability to perform simple calculations (the first question), understanding of how compound interest works (second question), and understanding of the effect of inflation (third question). We also designed questions to assess knowledge of the time value of money (fourth question) and whether respondents suffer from money illusion (fifth question). An understanding of these concepts is necessary for basic day-to-day financial transactions and financial planning. Responses to these questions are reported in Table 1A. Note that while many respondents answered some questions correctly, only $40.2 \%$ of respondents provided the correct answer to all five questions (Table 1B). Hence, while many respondents display some understanding of basic economic concepts, basic financial literacy is not widespread among the Dutch population.

We designed the second set of questions to measure advanced financial knowledge. Appendix B and Table 2A report the exact wording of the questions and document the responses to the advanced literacy questions. Clearly, these are much more complex questions that are devised to measure knowledge related to financial investments and portfolio choice. The questions assess knowledge of financial assets, such as stocks, bonds and mutual funds; the trade-off between risk and return; the understanding of risk diversification; the function of the stock market; and the relationship between bond prices and interest rates.

Table 2A shows that the response pattern for the advanced questions is much different than that for the basic literacy questions. Specifically, the number of correct answers is much lower; only about a quarter of respondents know about the relationship between bond prices and interest rates. Note that not only were respondents more likely to have given incorrect answers to these questions, but they also stated that they do not know the answer more often. For example, while $13 \%$ of respondents were incorrect about the main function of the stock market, 20\% stated they do not know the answer to this question. Table 2B shows that only $5 \%$ of respondents were able to answer all eleven advanced literacy questions correctly, while the fraction of incorrect or 'do not know' responses on several questions is sizable. These are important findings. For example, most life cycle models assume that consumers are well informed and have the capacity to make complex decisions, such as determining the optimal level of consumption over their lifetime. In fact, the findings presented in Tables 1A, 1B, $2 \mathrm{~A}$

\footnotetext{
${ }^{7}$ For an analysis of the module on financial literacy in the 2004 HRS, see Lusardi and Mitchell (2011b). For a review of financial literacy surveys across countries, see Lusardi and Mitchell (2007b, 2011c).
} 
and 2B show that financial literacy should not be taken for granted. These findings echo the results found in US surveys, such as the Health and Retirement Study and the Survey of Consumers, as well as findings from other countries (see Lusardi and Mitchell (2007a, 2011c) for a review).

We summarise the information on financial literacy derived from the responses to our two sets of questions into a financial literacy index. First, we perform a factor analysis on the sixteen financial literacy questions. Consistent with the way we designed the financial literacy survey, we find two main factors with different loading on the two sets of questions - the simple literacy questions (first 5 questions) and the more advanced literacy questions (remaining 11 questions). We therefore construct two literacy indices by performing a factor analysis on the two sets separately. The first index is related to basic knowledge while the second index measures more advanced financial knowledge. In constructing the indices, we explicitly take into account the differences between incorrect and 'do not know' answers (see Appendix C). It is important to use this information to differentiate between degrees of financial knowledge (see Lusardi and Mitchell, 2011b). Details about the factor analysis and descriptive statistics on the relationship between literacy and age, gender and education are provided by Van Rooij, Lusardi and Alessie (2011a).

\subsection{Wealth and literacy}

We aim to explore a new explanation for the heterogeneity in wealth holdings; specifically, the effects of financial literacy on wealth. First, we look at the bivariate relationship between wealth and our two measures of financial literacy. Table 3 documents a strong increase in median net worth at higher levels of both basic and advanced financial literacy. Focusing on advanced financial literacy and dividing the financial literacy indices in quartiles, we find that the median net worth of individuals in the top financial literacy quartile amounts to $€ 185900$, which is quadruple the median net worth of those in the bottom literacy quartile (€ 46700). The differences in wealth across basic financial literacy quartiles are large, although somewhat smaller than across advanced literacy quartiles. These simple correlations suggest a strong, non-linear gradient between financial literacy and net worth.

Table 4 shows a similar pattern for several asset categories. Home ownership and investments in stocks, mutual funds and bonds are much more common among those who score high on the financial literacy indices. Nevertheless there are notable differences between asset classes. While home ownership is not uncommon among individuals with low financial literacy, investments in stocks or bonds are almost absent in this subgroup. This evidence 
suggests that more financially literate households spread their wealth over a richer class of assets and hold more diversified portfolios.

\section{Wealth regressions}

To further investigate the relationship between household wealth and financial literacy, we start with a basic multivariate regression of total net worth on several controls and extend this specification by successively including additional determinants of wealth. Tables $5 \mathrm{~A}$ and $5 \mathrm{~B}$ report the results. First, we run an OLS regression of total net worth on our measure of basic financial literacy. Other control variables include gender, age and educational attainment, household composition (marital status and the number of children within the household), household net disposable income, and a dummy for whether the respondent is retired. We also include a dummy for the self-employed to account for their differences with respect to other households (Hurst and Lusardi, 2004).

Age and income appear to be strongly significant (Table 5A, column 1). Total net worth increases with age, but because we are using cross-sectional data, we cannot disentangle whether this is attributable to age or cohort effects. Nevertheless, this result is consistent with panel data evidence suggesting that Dutch households hardly decumulate private wealth after retirement (Kapteyn, Alessie and Lusardi, 2005; Alessie, Lusardi and Kapteyn, 1999). To capture complex, possibly non-linear effects of income on wealth accumulation, we include a polynomial for the natural logarithm of net disposable household income with a linear, quadratic and cubic term. A one percent increase in household income-measured at mean levels of the control variables-is associated with an increase in total net worth of about $€ 1400$.

Most importantly, we find there is a positive and statistically significant effect of basic financial literacy on total net worth. A unit increase in basic literacy is associated with an increase in wealth of about $€ 12000$ (the basic literacy measure itself has a zero mean and a standard deviation of one). Thus, respondents with higher basic knowledge are more likely to accumulate wealth. Nevertheless, it is not immediately clear whether this is the result of better financial decisions due, for example, to an ability to collect and process information at low cost and effort or, alternatively, to the association with personal characteristics such as risk aversion, time preference or overconfidence (see Christelis, Jappelli and Padula (2010) for a discussion).

To further investigate these issues, we first examine the role of confidence in financial knowledge in relation to actual financial knowledge. In addition to actual financial literacy, 
the perception of one's knowledge might assert an independent effect on financial outcomes, albeit the direction of the effect is not clear cut, a priori. Individuals who are overly modest about their knowledge might refrain from using new financial products and forego potential financial benefits. Insofar as high confidence in one's financial knowledge leads to less conservative portfolio management, it could have a positive impact on net worth. On the other hand, high-confidence individuals might buy products that they do not fully understand and end up making financial mistakes with potentially serious consequences. In addition, the literature on overconfidence offers arguments that individuals with too much trust in their knowledge may be inclined to interpret and filter information in accordance with their beliefs and might trade excessively (ending up with higher trading costs and lower net investment returns). Barber and Odean (2000, 2001), for instance, provide evidence of overconfident investors trading excessively and ending up with lower returns on their investments.

At the start of our survey, we ask respondents 'How would you assess your understanding of economics (on a 7-point scale; 1 means very low and 7 means very high)?' Based upon this self-assessment, we construct a relative measure of overconfidence. The selfassessment and our basic financial literacy index are not directly comparable due to the use of different scales but do provide information on the relative position of respondents within the distribution of actual basic literacy and self-assessed literacy, respectively. We start with grouping both variables into four categories and ranking the respondents accordingly from the top category to the lowest group. Thereafter, we create a dummy for overconfidence that equals one if the respondents' self-assessed literacy ranking is higher than our classification of basic financial literacy. Similarly, we construct a dummy for underconfidence when the ranking on self-assessed literacy is lower than warranted by the actual measures of literacy. Thereafter, we rerun the wealth regression, this time including the overconfidence and underconfidence dummies (the reference group being the respondents with an assessment of their literacy in line with their actual knowledge). Appendix C provides more detail on the construction of the confidence measures. Our main interest is whether the effect of basic financial ability on wealth accumulation is affected by the inclusion of these confidence measures. The coefficient of basic financial literacy remains significant and increases somewhat (Table 5A, column 2). ${ }^{8}$ The coefficient of overconfidence is negative but insignificant. Underconfidence, however, has a significant negative impact on net worth.

\footnotetext{
${ }^{8}$ The number of observations has now decreased from 1091 to 1060 as, in constructing the measures for underand overconfidence, we omit respondents answering 'do not know' when asked to assess their economics knowledge.
} 
Compared to individuals with correct assessment of their financial knowledge, underconfident respondents do not seem to take full advantage of their knowledge, at least in relation to savings.

Experimental evidence reveals that individuals with lower cognitive ability are likely to be less risk tolerant and more impatient (Benjamin, Brown and Shapiro, 2006; Dohmen, Falk, Huffman and Sunde, 2010). To test whether the effect of basic financial literacy is due to an association with risk attitude, we include a measure of risk aversion. In the annual DHS respondents are asked to indicate to what extent they agree with the statement, 'Investing in stocks is something I don't do, since it is too risky'. The response scale runs from 1 to 7 , with 1 indicating 'complete disagreement' and 7 'complete agreement'. Kapteyn and Teppa (2011) show that this measure has more explanatory power in models of portfolio choice than measures of risk tolerance based on a series of hypothetical choices between uncertain streams of lifetime income, as proposed by Barsky, Juster, Kimball and Shapiro (1997). The regression results in Table 5A (column 3$)^{9}$ show that there is indeed an important role for risk aversion in explaining wealth heterogeneity, but the coefficient of basic financial literacy is virtually unaffected. ${ }^{10}$

We subsequently test whether financial literacy serves as a proxy for patience. We do not have direct information on time preferences, but we include information on smoking and drinking behaviour as a proxy for myopic behaviour, as is done in many other studies since the work by Fuchs (1980) on the relationship between different types of health decisions and patience. We use information on whether individuals smoke and how often, and on whether they are heavy drinkers (defined as more than four alcoholic drinks on average per day). We do not find any relationship between net worth and these proxies for time preference, and the coefficient estimate of the basic financial literacy index changes only marginally (Table 5B, column 1).

In the next step, we investigate whether basic financial ability could be a proxy for advanced financial knowledge (as suggested by the results in Van Rooij, Lusardi and Alessie, 2011a) and include the measure of advanced financial literacy. Indeed the effect of advanced literacy is strongly significant, reduces the coefficient estimate on basic financial capacity and

\footnotetext{
${ }^{9}$ The information on risk aversion and time preferences is available in the DHS modules on saving attitudes, income and health. By merging different modules, the total number of observations in our regression is reduced by 57 (even though we are able to retain some households by using information on time preferences and risk tolerance from adjacent years).

${ }^{10}$ As a robustness check we have included the Barsky et al. (1997) measure of risk tolerance, as it has proved to be a valuable measure in other papers (e.g., Van Rooij, Kool and Prast, 2007), but it turned out to be insignificant, confirming the results of Kapteyn and Teppa (2011).
} 
wipes out its significance (Table 5B, column 2). The coefficient of advanced literacy is higher than the one of basic literacy index; a unit increase in advanced financial literacy raises household net worth by $€ 24000$. However, we need to be cautious about the interpretation of the OLS estimates of financial literacy. While the basic financial literacy index touches upon skills that individuals need on a daily basis, the advanced literacy index includes questions on the workings of stocks, bonds and mutual funds, which are complex concepts beyond what is needed to know to perform basic financial transactions. It is conceivable that the desire to increase wealth may foster investing in financial knowledge; as a result, the OLS coefficient could be biased upwards (simultaneity bias). Moreover it is conceivable that advanced financial literacy is related to some unobserved variables that also affect wealth holdings. ${ }^{11}$ On the other hand, the advanced literacy index might be a noisy measure of actual advanced financial knowledge and the coefficient of advanced financial literacy could be biased toward zero (attenuation bias). Indeed Van Rooij, Lusardi and Alessie (2011a) provide evidence that a slight variation in the wording of some of the advanced literacy questions affects response patterns, which suggests that respondents have a tendency to guess the answer to financial literacy questions, in particular the complex ones.

To address the nexus of causality, we perform instrumental variables (IV) estimation. We use economics education as an instrument for advanced financial literacy. This variable measures exposure to education before entering the job market. It is based upon the answers to the question 'How much of your education was devoted to economics?' with response categories being 'a lot', 'some', 'little', and 'hardly at all'. It has strong predictive power for advanced financial literacy, as shown by the test on the relevance of the instruments in the first stage regression (Table 5B, column 3 ). The $F$-value equals 13 , clearly above 10 -the value that is often recommended as a rule of thumb to avoid the problem of weak instruments (Staiger and Stock, 1997). We assume that this information is unrelated to the error term in the wealth equation. We are aware that this criterion might not be met because of simultaneity and/or omitted variable bias, and insofar as possible we have tried to address this issue by adding other relevant control variables (see next section). Nevertheless the IV results should be interpreted with caution.

The IV estimates show that the coefficient measuring the effect of financial literacy on net worth remains significant at the $5 \%$ level and increases in magnitude with respect to the OLS estimate. Overall, our estimates are in line with the hypothesis that financial literacy is

\footnotetext{
${ }^{11}$ For the same reason our proxy for basic financial literacy could be an endogenous variable. However, the DHS does not contain instruments for both financial literacy variables.
} 
positively related to wealth accumulation, even after accounting for attitudes and preferences that might be associated with an individual's level of financial literacy.

\section{Extensions}

To investigate the robustness of our findings, we exploit the richness of the DHS dataset and examine a variety of extensions and alternative specifications of the wealth regressions. ${ }^{12}$ A potential concern with our instrument is that accumulating wealth and becoming financially literate or being exposed to economics education are choice variables that depend on a common unobserved factor or an omitted variable. One possible candidate for a variable that drives literacy, education and wealth but is usually unavailable in wealth regressions is ability, as some individuals are intrinsically more gifted and have better basic cognitive skills than others. For this reason, we use the basic literacy variable in the wealth regressions to control for cognitive ability.

Carefulness is an example of a common trait that perhaps has not yet been taken into account. Careful individuals, who take many precautions to prevent bad things happening to them, could be more likely to hold a buffer stock of savings and to invest in financial education, as well, to lower the chance of facing financial difficulties. To explore this possibility, we run two additional specifications, which include information from two separate questions. Respondents were asked whether they consider themselves to be a 'careful person' and whether they 'take many precautions'. The response scales run from 1 (completely disagree) to 7 (completely agree). By merging this information with our data, we lose close to 300 observations. Due to the lower number of observations, the $F$-value of the joint significance of the dummies for economics education (our instrument) in the first stage regression decreases to 6 but remains strongly significant. The inclusion of how careful respondents are does not take away the effect of financial literacy on net worth. The advanced literacy coefficient remains significant at the $5 \%$ confidence level and even increases in value.

Other potential drivers of wealth heterogeneity could be related to financial literacy and might influence the relationship between financial literacy and the accumulation of wealth. In this section we further exploit the richness of the DHS dataset to investigate whether the importance of financial literacy is lessened once we control for alternative explanations of the wealth dispersion. One potential explanation for wealth heterogeneity is simply that households have different appetites for saving. Venti and Wise (1998) conclude, for example, that unobserved heterogeneity in the propensity to save must be a major driving

\footnotetext{
${ }^{12}$ See Van Rooij, Lusardi and Alessie (2011b) for details.
} 
factor for wealth inequality after having successively eliminated lifetime earnings, chance events and investment choices as explanations for the wide differences in wealth holdings. Our dataset does contain a direct proxy for the propensity to save, which is measured by the responses to what respondents 'do with money that is left over after having paid for food, rent, and other necessities'. The response scale runs from 1 to 7, in which 1 means 'I like to spend all my money immediately' and 7 means 'I want to save as much as possible'. Our estimates show that, across the board, a higher appetite for saving translates into higher saving accumulation. However, the magnitude and significance of the coefficient of advanced financial literacy is unaffected when this additional control for saving is added.

Self-control is indisputably an important factor in saving outcomes (Thaler, 1994). No matter how much importance individuals attach to saving, if they have difficulties withstanding short-term temptation and do not find ways to constrain their consumption behaviour, they will not be able to save. The DHS question asking whether respondents 'find it difficult to control their expenditures' (on a scale from 1 to 7, in which 1 means 'very easy' and 7 means 'very difficult') provide a way to measure self-control. We find that self-control is a major determinant of wealth accumulation. The difference between those who have little or no difficulty controlling their expenditures and those who recognise that this is a major challenge is nearly $€ 90000$ in net worth. The inclusion of self-control, however, does not fundamentally affect the relationship between financial literacy and wealth accumulation. ${ }^{13}$

In addition to these extensions we incorporate a large number of variables that, based upon the theoretical and empirical literature, could account for part of the variation in net worth among households. To this end, we merge our data with information from other DHS modules. We include several alternative health measures, respondent self-assessed probability for survival until a certain age (to account for heterogeneity with respect to perceived longevity), income uncertainty, expectations regarding housing prices, perceived likelihood of future reduction in the generosity of the state pension, and expected replacement rate (based upon state pension eligibility and mandatory employer company savings). All of these variables are insignificant and do not affect the coefficient estimates of financial literacy on wealth. $^{14}$

We test the robustness of our results to other measures of wealth. Using net worth over permanent income as a dependent variable (permanent income is calculated from an auxiliary

\footnotetext{
${ }^{13}$ We have also accounted for a bequest motive and for planning horizons. Our main results are unchanged. See Van Rooij, Lusardi and Alessie (2011b).

${ }^{14}$ For brevity, estimates are not reported but are available upon request.
} 
regression of income on a number of demographics), we attain estimation results which corroborate the evidence of a positive and significant relationship between financial literacy and wealth. Finally, we use alternative instrument sets using information about the financial condition of siblings and knowledge of parents. While the financial condition and knowledge of others are not under control of the respondent, witnessing financial problems of the oldest sibling or parents may provide strong motivation to acquire financial knowledge (see Van Rooij, Lusardi and Alessie, 2011a). Using these alternative instruments, we find that the IV estimate for financial literacy remains strongly significant and increases somewhat in value, while the estimates of the other coefficients do not change qualitatively. These extensions and alternative empirical strategies show that the impact of financial literacy on net wealth is robust.

\section{Discussion}

Many policymakers are concerned about the adequacy of retirement savings. When households do not accumulate sufficient wealth, there are profound implications not only for personal welfare but also for public policy, as low-savings households may lack a buffer to deal with negative shocks and are more likely to become dependent on public support. However, the debate on whether household savings are too low is still ongoing. Many studies conclude that a large number of households have insufficient retirement savings. Other studies suggest that for the majority of households, wealth accumulation is adequate, once changing consumption needs over the life cycle are taken into account. From this perspective, it is not clear that increasing financial literacy would necessarily result in higher saving rates.

An important policy question is whether financial education stimulates wealth accumulation or whether the causality runs the other way. Gustman, Steinmeier and Tabatabai (2010) argue that the causality might run from wealth to financial literacy. Individuals who accumulate a lot of wealth also face an incentive to become financially knowledgeable and have the opportunity to acquire knowledge by managing their portfolio. The results by Bernheim, Garrett and Maki (2001), on the other hand, suggest that high school programs aimed at increasing financial knowledge stimulate savings. If the direction of causality runs from financial knowledge to increased savings, it is important to understand how financial literacy translates into increased savings as it might be attractive from a public policy point of view to invest in financial education initiatives if, for example, household savings are deemed too low. We discuss two possible explanations related to the well-documented limited stock 
market participation puzzle and to another puzzling fact of household finance, i.e., the lack of retirement planning.

\subsection{Financial literacy and stock market participation}

Economic theory dictates that (with the possible exception of a small proportion of households) it is optimal to hold a portion of household wealth in the form of stocks (Haliassos and Bertaut, 1995). Investing in the stock market provides an opportunity to take advantage of the equity premium and to benefit from risk diversification. In fact, evidence on the composition of household portfolios across countries shows that many households have no stocks at all in their portfolios (Guiso, Haliassos and Jappelli, 2002). In our sample, about a quarter of the households invest in stocks, either directly or indirectly via mutual funds. Limited participation in stock markets is often traced back to transaction costs and the costs of processing information, which create a threshold for entering the stock market (Haliassos and Bertaut, 1995; Vissing-Jorgenson, 2004). In addition, it has been argued that households are either simply unaware of the investment opportunities in the stock market or refrain from investing in stocks due to a lack of trust (Guiso and Jappelli, 2005; Guiso, Sapienza and Zingales, 2008).

An increase in financial literacy lowers information costs as well as decreases impediments to participating in the stock market. Indeed, our work - relying on both OLS and IV estimates - shows that the probability of owning stocks or mutual funds in the Netherlands increases with the level of financial literacy (Van Rooij, Lusardi and Alessie, 2011a). Because financial knowledge increases stock ownership, high-knowledge individuals have an opportunity to exploit the risk premium on equity investments, and doing so might contribute to the positive effect of financial literacy on net worth. This is true regardless of the fact that some households may in fact be better off not investing in the stock market due to excessive trading or bad timing of transactions, as the financial literature shows that the vast majority of households that invest in the stock market follow very passive investment strategies (see, e.g., Ameriks and Zeldes, 2004).

\subsection{Financial literacy and retirement planning}

A second potentially important channel through which financial literacy impacts wealth accumulation is via retirement and financial planning. As an example, the model by Reis (2006) distinguishes inattentive consumers who do not plan and do not accumulate wealth from those who do plan and thereby accumulate savings. Empirical evidence supports 
the assertion that retirement planning affects wealth accumulation (Lusardi, 1999; Lusardi and Mitchell, 2007a, 2009, 2011b; Ameriks, Caplin and Leahy, 2003). Planning is an inherently complex task; for example, one needs to collect and process a lot of information. Thus, the effect of financial literacy on total net worth might be related to the capacity to plan. ${ }^{15}$ Indeed, Lusardi and Mitchell (2009) offer convincing evidence of financial literacy fostering thinking about retirement. In another study, Lusardi and Mitchell (2008, 2011b) document a positive relationship between simple measures of financial knowledge and more specific measures of retirement planning related to the calculation of saving needs after retirement. In the following section, we take these two approaches a step further by relating retirement planning to comprehensive measures of financial literacy.

Our survey module contains a series of questions on retirement planning that were originally developed by Lusardi and Mitchell (2011b) for a module in the 2004 HRS. The first question relates to the very first step in setting up a retirement plan: 'Have you ever tried to figure out how much your household would need to save for retirement?' Of 1508 respondents, 564 answered affirmatively and are labelled 'simple' planners. Respondents who answered 'yes' were given the follow-up question, 'Have you developed a plan for retirement saving?' The majority of respondents seems to have developed some sort of a retirement savings plan, as 161 plus 299 respondents answered 'yes' or 'more or less', respectively. Out of this group of 'serious' planners, the large majority claims to have been successful planners, in the sense that 169 plus 250 respond 'always' or 'mostly' to the third question: 'How often have you been able to stick to this plan'. The proportion of simple, serious and successful planners is roughly comparable to that found for US households surveyed in the 2004 HRS, although the latter is based on a sample of older households (Lusardi and Mitchell, 2011b). The weighted percentage of simple, serious and successful planners in our sample equals 34.6, 27.6, and 25.1 respectively.

Descriptive statistics on retirement planning and demographics are reported in Tables 6 and 7. As expected, there is a strong correlation with age. The closer individuals get to retirement, the more likely they are to have started considering their retirement needs. We find no differences in planning activities between men and women, while couples are more

\footnotetext{
${ }^{15}$ Even if individuals rely on financial planners or advisors, they have to come up with a lot of information, some of which is complex to retrieve and communicate (e.g., information on their preferences and the uncertainty around the main scenario they foresee). At the same time, consumers have to be savvy enough to understand the implications of the advice given by planners or advisors and to judge whether the suggested plans fit their needs. Interestingly, a multivariate regression analysis reveals that financial literacy does not exert an independent effect on the probability of consulting a financial intermediary. Illiterate households do however rely significantly more on the advice of friends and acquaintances when making important financial decisions (results are available upon request).
} 
likely to be successful in executing their plans. While there is not much evidence that planning is related to education or basic literacy, there is a strong correlation of planning with advanced financial literacy. The proportion of planners in the most literate group is almost double the number for households with the lowest level of financial knowledge. Another notable result is the role of confidence. Those who are very confident in their economics knowledge are more likely to calculate how much they need to save for retirement purposes. This suggests that concerns about knowledge and capacity to handle complex retirement savings decisions prevent individuals from attempting to calculate retirement savings needs and set up plans.

The relationship between financial literacy and simple retirement planning is confirmed in a multivariate regression analysis including the same explanatory variables as used previously (Table 8). We report both OLS and IV regressions, as we are cautious about possible simultaneity bias; one could attain financial knowledge in the process of calculating savings needs and developing and executing a retirement plan. However, conditionally upon the validity of our instrument set, the IV estimates point to a downward bias in the OLS estimates, potentially due to the problem of measurement error in the advanced financial literacy index. A one standard deviation increase in financial literacy increases the probability of planning for retirement by more than 20 percentage points.

One explanation why retirement planning may affect wealth is via its effect on selfcontrol. If consumers want to save but simply lack the discipline to do so, planning may help consumers control their consumption (Ameriks, Caplin, Leahy and Tyler, 2007). Moreover, research from psychology shows that people are more likely to achieve goals and translate intentions into actions when they develop specific plans. ${ }^{16}$

The relationship between financial literacy and planning is a pretty robust finding. Alessie, Van Rooij and Lusardi (2011) use a different measure of planning (how much individuals have thought about retirement) and a simple measure of financial literacy which was collected in the DHS in 2010. Both the OLS and IV estimates continue to show a positive and statistically significant effect of financial literacy on retirement planning.

Critics might argue that, in the Netherlands, it is not clear that financially knowledgeable individuals will be induced to save more for retirement when comparing expected retirement income with their spending needs. ${ }^{17}$ After performing this comparison,

\footnotetext{
${ }^{16}$ See Lusardi and Mitchell (2007a) for a more detailed discussion of the explanations why retirement planning affects wealth.

${ }^{17}$ Also for the US, the conclusion—drawn in many studies—-that retirement savings are insufficient is not undisputed (Scholz, Seshadri and Khitatrakun, 2006).
} 
individuals could find that they are currently holding excessive wealth and adjust their savings downward, since the Dutch pension system is known to be relatively generous, and the vast majority of employees save via mandatory defined benefit retirement plans with compulsory contributions (Van Rooij, Kool and Prast, 2007). In fact, research shows that the replacement rates provided by the Dutch mandatory pension system are, in many cases, lower than expected by many employees and insufficient to provide the desired standard of living in old age (Van Duijn, Lindeboom, Lundborg and Mastrogiacomo, 2009; Binswanger and Schunk, 2008). This suggests that making retirement calculations and subsequently developing targets for spending and saving might help households boost their wealth.

\subsection{The cost of ignorance}

The association between advanced financial literacy and wealth accumulation that we have found is not only statistically significant but also quantitatively large. The net worth difference associated with the difference in the $75^{\text {th }}$ and $25^{\text {th }}$ percentiles of the advanced financial literacy index equals $€ 80000$, i.e., roughly three and a half times the net disposable income of a median household. ${ }^{18}$ This number provides a crude proxy for the economic relevance of the financial literacy-wealth coefficient. Similar calculations show that higher levels of financial literacy are associated with economically meaningful increases in the propensity to participate in stock markets and to plan for retirement. An increase in advanced financial literacy from the $25^{\text {th }}$ to the $75^{\text {th }}$ percentile for an individual with otherwise average characteristics is associated with a 17 and 30 percentage point higher probability of stock market participation and retirement planning, respectively. ${ }^{19}$ Large differences in financial knowledge correlate with important differences in financial behaviour. While we have addressed the concern of reverse causality to the extent possible within our dataset, we do not claim that we have resolved the dispute about the direction of causality of the literacy-wealth relationship. Nevertheless, our results show that if one is willing to believe that there is an effect of literacy on financial behaviour, the potential benefits of financial education are substantial, and the costs of financial ignorance are potentially large.

How do our findings compare to the economic effects reported in other studies? Campbell (2006) argues that suboptimal refinancing among US home owners results, on average, in $0.5-1 \%$ higher mortgage interest rates, depending on the year under consideration.

\footnotetext{
${ }^{18}$ In the calculations we use the coefficient and confidence interval for the effect of advanced financial literacy on wealth from the preferred IV specification among the regressions in Table 5B (see column 3).

${ }^{19}$ See also Van Rooij, Lusardi and Alessie (2011b).
} 
Given the current size of the US mortgage market, this is equivalent to $\$ 50-100$ billion additional annual interest costs paid. US investors are estimated to have foregone $0.67 \%$ of average annual equity return because of fees, expenses and trading costs of active investment strategies in an attempt to beat the market (French, 2008). This amounts to a total annual cost of about $\$ 100$ billion that could have been saved by passively following the market portfolio. Bovenberg, Koijen, Nijman and Teulings (2007) calibrate a stylised life cycle savings model with portfolio investments. Compared to an optimal investment strategy, their parameter choices yield a welfare loss of 3.5\% for underdiversification and a 12\% loss when individuals do not participate in the stock market at all (either directly or indirectly via pension savings). Using different values for several parameters of interest and comparing to a benchmark situation which takes borrowing constraints into account, Cocco, Gomes and Maenhout (2005) report welfare losses of up to $4 \%$ from non-participation in the stock market. Calvet, Campbell and Sodini (2007) estimate an actual annual return loss due to lack of participation in the stock market by Swedish households that could be as large as $4.3 \%$. Calvet, Campbell and Sodini (2007) also provide estimates for the economic cost of under-diversification based upon the actual portfolio composition of Swedish investors. For a median investor, the annual return loss due to under-diversification is $2.9 \%$ on the risky portfolio, which equals $\$ 129$ or $0.5 \%$ of household disposable income. However, for one in ten investors, these annual costs are as high as $\$ 1190$ (4.5\% of disposable income) or more.

These figures are not directly comparable to the estimated wealth-financial literacy relationship in our regressions. First, the numbers reported are very specific to certain types of portfolio behaviour. Second, they represent a flow of foregone returns, while wealth is a stock variable. While recognizing that our calculations provide only crude approximations, the effect of financial literacy could be substantial. Investing in financial education is attractive in terms of wealth holdings insofar as these efforts boost financial knowledge. For the ultimate impact on personal welfare, though, it makes a difference whether higher wealth holdings come from improved wealth management, leading to the avoidance of financial mistakes and to higher portfolio returns, or alternatively are the result of households being in a better position to plan their expenses. The two channels that we have highlighted (stock market participation and retirement planning) are examples of both mechanisms. That said, it is important to realise that any effect of financial education on household wealth is not immediate and may take time to materialise. 


\section{Concluding remarks}

Financial literacy and its effect on economic decisions have become an important topic. It is obvious that the management of wealth and portfolio choice requires more sophisticated knowledge than it did two or three decades ago. Not only have households become more and more responsible for their well-being but the landscape of financial markets has changed dramatically, and these changes have been characterised by an increase in the complexity of financial products. In this study, we use detailed measures for basic and more advanced financial literacy, and we document evidence of an independent positive association between financial literacy and wealth accumulation. The effect of financial literacy on accumulated savings is robust across different specifications and continues to hold even after we control for many other wealth determinants.

We have highlighted and documented evidence of two important channels that might contribute to the relationship between wealth accumulation and financial literacy: financially knowledgeable individuals are (1) more likely to invest in stocks and (2) have a higher propensity to plan for retirement. We argue that this is because financial literacy lowers the costs of collecting and processing information and reduces planning costs, thereby facilitating the execution of financial decisions and bringing down economic and psychological thresholds for stock market participation or retirement savings calculations and subsequent development of retirement plans.

Our study is complementary to those by Bernheim, Garrett and Maki (2001) and Bernheim and Garrett (2003) that have shown that financial education in the US (either in high school or via workplace seminars) has a positive impact on savings but have not been able to identify whether this effect is due to individual appetites for saving, provision of information and supply of commitment devices, a broad improvement in financial literacy and reduction of financial mistakes, or peer effects. Our work shows that financial literacy is positively associated with wealth accumulation, but we cannot infer from this result that the effect of financial education programs is indeed the result of an increase in financial literacy. ${ }^{20}$ To assess that finding, we need to be able to separate the impact of financial education on financial ability and knowledge from other channels.

\footnotetext{
${ }^{20}$ Interestingly, further analysis shows that peer effects might indeed play an important role in financial behaviour, especially for those with less financial literacy as they are more likely to cite friends and relatives as their most important source of advice on financial decisions (Lusardi and Mitchell, 2011b; Van Rooij, Lusardi and Alessie, 2011a).
} 


\section{References}

Agarwal, S., Driscoll, J., Gabaix, X. and Laibson, D. (2009). 'The age of reason: Financial decisions over the lifecycle with implications for regulation', Brookings Papers on Economic Activity, Fall 2009, pp. 51-101.

Agnew, J., Szykman, L., Utkus, S. and Young, J. (2007). 'Literacy, trust and 401(k) savings behavior’, Center for Retirement Research Working Paper, 2007-10, Boston.

Alessie, R., Lusardi, A. and Kapteyn, A. (1999). 'Saving after retirement: Evidence from three different surveys’, Labour Economics, vol. 6(2), pp. 277-310.

Alessie, R., Van Rooij, M. and Lusardi, A. (2011). 'Financial literacy and retirement preparation in the Netherlands', forthcoming Journal of Pension Economics and Finance.

Ameriks, J., Caplin, A. and Leahy, J. (2003). 'Wealth accumulation and the propensity to plan’, Quarterly Journal of Economics, vol. 118(3), pp. 1007-1047.

Ameriks, J., Caplin, A., Leahy, J. and Tyler T. (2007). 'Measuring self-control problems', American Economic Review, vol. 97(3), pp. 966-72.

Ameriks, J., and Zeldes, S. (2004). 'How do household portfolio shares vary with age?', mimeo, Columbia Graduate School of Business.

Barber, B., and Odean, T. (2000). 'Trading is hazardous to your wealth: The common stock investment performance of individual investors', Journal of Finance, vol. 55(2), pp. 773-806.

Barber, B., and Odean, T. (2001). 'Boys will be boys: Gender, overconfidence, and common stock investment’, Quarterly Journal of Economics, vol. 116(1), pp. 261-292.

Barsky, R., Juster, F., Kimball, M. and Shapiro, M. (1997). 'Preference parameters and behavioral heterogeneity: An experimental approach in the Health and Retirement Study', Quarterly Journal of Economics, vol. 112(2), pp. 537- 79.

Benartzi, S., and Thaler, R. (2004). 'Save more tomorrow. Using behavioral economics to increase employee saving', Journal of Political Economy, vol. 112(1), pp. 164-87.

Benjamin, D., Brown, S. and Shapiro, J. (2006). 'Who is 'behavioral'?: Cognitive ability and anomalous preferences', mimeo, Harvard University.

Bernheim, D. (1995). 'Do households appreciate their financial vulnerabilities? An analysis of actions, perceptions, and public policy’. In: Tax Policy and Economic Growth, , pp. 1-30, Washington, DC: American Council for Capital Formation.

Bernheim, D. (1998). 'Financial illiteracy, education and retirement saving' in (O. Mitchell and S. Schieber, eds.), Living with Defined Contribution Pensions, pp. 38-68, Philadelphia: University of Pennsylvania Press. 
Bernheim, D., Garrett, D. and Maki, D. (2001). 'Education and saving: The long-term effects of high school financial curriculum mandates', Journal of Public Economics, vol. 80(3), pp. 435-65.

Bernheim, D., and Garrett, D. (2003). 'The effects of financial education in the workplace: Evidence from a survey of households', Journal of Public Economics, vol. 87(7), pp. 14871519.

Bernheim, D., Skinner, J. and Weinberg, S. (2001). 'What accounts for the variation in retirement wealth among U.S. households?', American Economic Review, vol. 91(4), pp. 83257.

Binswanger, J., and Schunk, D. (2008). 'What is an adequate standard of living during retirement?’, CentER Discussion Paper, 82, Tilburg University.

Bovenberg, L., Koijen, R., Nijman, T. and Teulings, C. (2007). 'Saving and investing over the life cycle and the role of collective pension funds', De Economist, vol. 155(4), pp. 347-415.

Browning, M., and Lusardi, A. (1996). 'Household saving: Micro theories and micro facts', Journal of Economic Literature, vol. 34(4), pp. 1797-1855.

Calvet, L., Campbell, J. and Sodini, P. (2007). 'Down or out: Assessing the welfare costs of household investment mistakes’, Journal of Political Economy, vol. 115(5), pp. 707-47.

Campbell, J. (2006). 'Household finance’, Journal of Finance, vol. 61(4), pp. 1553-1604.

Chan, S., and Stevens, A. (2008). 'What you don't know cannot help you: Pension knowledge and retirement decision-making, Review of Economics and Statistics, vol. 90(2), pp. 253-66.

Christelis, D., Jappelli, T. and Padula, M. (2010). 'Cognitive abilities and portfolio choice', European Economic Review, vol. 54(1), pp. 18-39.

Clark, R., and D'Ambrosio, M. (2008). 'Adjusting retirement goals and saving behavior: The role of financial education.' in: (A. Lusardi, ed.), Overcoming the Saving Slump: How to Increase the Effectiveness of Financial Education and Saving Programs, pp. 237-56, Chicago: University of Chicago Press.

Cocco, J., Gomes, F. and Maenhout, P. (2005). 'Consumption and portfolio choice over the life-cycle’, Review of Financial Studies, vol. 18(2), pp. 490-533.

Cole, S., and Shastry, G. (2008). 'If you are so smart, why aren't you rich? The effects of education, financial literacy and cognitive ability on financial market participation', Working paper, Wellesley College.

Duflo, E., and Saez, E. (2003), 'The role of information and social interactions in retirement plan decisions: Evidence from a randomized experiment', Quarterly Journal of Economics, vol. 118(3), pp. 815-42.

Duflo, E., and Saez, E. (2004). 'Implications of pension plan features, information, and social interactions for retirement saving decisions', in (O. Mitchell and S. Utkus, eds.), Pension 
Design and Structure: New Lessons from Behavioral Finance, pp. 137-53, Oxford: Oxford University Press.

Dohmen, T., Falk, A., Huffman, D. and Sunde, U. (2010). 'Are risk aversion and impatience related to cognitive ability?’, American Economic Review, vol. 100(3), pp. 1238-60.

French, K. (2008). 'The cost of active investing', Journal of Finance, vol. 63(4), pp. 1537-73.

Fuchs, V. (1980). 'Time preference and health: An explorative study', NBER Working Paper, 539, NBER.

Guiso, L., and Jappelli T. (2005). 'Awareness and stock market participation', Review of Finance, vol. 9(4), pp. 537-67.

Guiso, L., Haliassos, M. and Jappelli, T. (2002). Household portfolios, Cambridge: MIT Press.

Guiso, L., Sapienza, P. and Zingales, L. (2008). 'Trusting the stock market', Journal of Finance, vol. 63(6), pp. 2557-2600.

Gustman, A., Steinmeier, T. and Tabatabai, N. (2008). 'Do workers know about their pensions? Comparing workers and employers' pension information', in (A. Lusardi ed.), Overcoming the Saving Slump: How to Increase the Effectiveness of Financial Education and Saving Programs, pp.47-81, Chicago: University of Chicago Press.

Gustman, A., Steinmeier, T. and Tabatabai, N. (2010). 'Financial knowledge and financial literacy at the household level’, NBER Working Paper, 16500, NBER.

Haliassos, M., and Bertaut, C. (1995). 'Why do so few hold stocks?', Economic Journal, vol. 105(432), pp. 1110-29.

Hilgert, M., Hogarth, J. and Beverly, S. (2003). 'Household financial management: The connection between knowledge and behavior’, Federal Reserve Bulletin, pp. 309-22.

Hubbard, R., Skinner, J. and Zeldes, S. (1995). 'Precautionary savings and social insurance', Journal of Political Economy, vol. 103(2), pp. 360-99.

Hurd, M. (1989). ‘Mortality risk and bequests', Econometrica, vol. 57(4), pp. 779-813.

Hurst, E., and Lusardi, A. (2004). 'Liquidity constraints, household wealth and entrepreneurship’ Journal of Political Economy, vol. 112(2), pp. 319-47.

Kapteyn, A., Alessie, R. and Lusardi, A. (2005). 'Explaining the wealth holdings of different cohorts: Productivity growth and social security’, European Economic Review, vol. 49(5), pp. 1361-91.

Kapteyn, A., and Teppa, F. (2011). 'Subjective measures of risk aversion, fixed costs, and portfolio choice’, Journal of Economic Psychology, vol. 32(4), pp. 564-80. 
Kimball, M., and Shumway, T. (2006). 'Investor sophistication, and the participation, home bias, diversification, and employer stock puzzles’, mimeo, University of Michigan.

Laibson, D. (1997), 'Golden eggs and hyperbolic discounting', Quarterly Journal of Economics, vol. 112(2), pp. 443-77.

Lusardi, A. (1999). 'Information, expectations, and savings for retirement', in (H. Aaron ed.), Behavioral Dimensions of Retirement Economics, pp. 81-115, Washington D.C.: Brookings Institution Press and Russell Sage Foundation.

Lusardi, A. (2003). 'Planning and saving for retirement', Working Paper, Dartmouth College.

Lusardi, A. (2004). 'Saving and the effectiveness of financial education', in (O. Mitchell and S. Utkus, eds.), Pension Design and Structure: New Lessons from Behavioral Finance, pp. 157-184, Oxford: Oxford University Press,.

Lusardi, A., and Mitchell, O. (2007a). 'Baby boomers retirement security: The role of planning, financial literacy and housing wealth’, Journal of Monetary Economics, vol. 54(1), pp. 205-24.

Lusardi, A., and Mitchell, O. (2007b). 'Financial literacy and retirement preparedness: Evidence and implications for financial education', Business Economics, vol. 42(1), pp. 3544.

Lusardi, A., and Mitchell, O. (2008). 'Planning and financial literacy: How do women fare?' American Economic Review, vol. 98(2), pp. 413-417.

Lusardi, A., and Mitchell, O. (2009). 'How ordinary consumers make complex economic decisions: Financial literacy and retirement readiness', NBER Working Paper, 15350, NBER.

Lusardi, A., and Mitchell, O. (2011a). 'The outlook for financial literacy', in (A. Lusardi and O. Mitchell, eds.), Financial Literacy: Implications for Retirement Security and the Financial Marketplace, Forthcoming Oxford University Press.

Lusardi, A., and Mitchell, O. (2011b). 'Financial literacy and planning: Implications for retirement wellbeing', in (A. Lusardi and O. Mitchell, eds.), Financial Literacy: Implications for Retirement Security and the Financial Marketplace, Forthcoming Oxford University Press.

Lusardi, A., and Mitchell, O. (2011c). 'Financial literacy around the world: an overview', forthcoming Journal of Pension Economics and Finance.

Modigliani, F., and Brumberg, R. (1954). 'Utility analysis and the consumption function: An interpretation of cross-section data', in (K. Kurihara, ed.), Post-Keynesian Economics, pp. 388-436, New Brunswick, New Jersey: Rutgers University Press.

Moore, D. (2003). 'Survey of financial literacy in Washington State: Knowledge, behavior, attitudes and experiences', Technical report 03-39, Social and Economic Sciences Research Center, Washington State University. 
Organization for Economics Co-Operation and Development (2005). Improving financial literacy: Analysis of issues and policies, Paris, France.

Reis, R. (2006). 'Inattentive consumers', Journal of Monetary Economics, vol. 53(8), pp. 1761-1800.

Rosen, H., and Wu, S. (2004). 'Portfolio choice and health status', Journal of Financial Economics, vol. 72(3), pp. 457-84.

Scholz, J., Seshadri, A. and Khitatrakun, S. (2006). 'Are Americans saving “optimally” for retirement?’, Journal of Political Economy, vol. 114(4), pp. 607-43.

Smith, B., and Stewart, F. (2008), 'Learning from the experience of OECD countries: Lessons for policy, programs, and evaluations', in (A. Lusardi, ed.), Overcoming the Saving Slump: How to Increase the Effectiveness of Financial Education and Saving Programs, pp. 354-68, Chicago: University of Chicago Press.

Staiger, D., and Stock, J. (1997). 'Instrumental variables regression with weak instruments', Econometrica, vol. 65(3), pp. 557-86.

Thaler, R. (1994). 'Psychology and savings policies', American Economic Review, vol. 84(2), pp. 186-92.

Van Duijn, M., M. Lindeboom, P. Lundborg, and M. Mastrogiacomo (2009). 'Pension plans and retirement replacement rates’, Netspar Discussion Paper, 2009-57, Tilburg University.

Van Els, P., Van den End, W. and Van Rooij, M. (2004). 'Pensions and public opinion: A survey among Dutch households’, De Economist, vol. 152(1), pp. 101-16.

Van Rooij, M., Kool, C. and Prast, H. (2007). 'Risk-return preferences in the pension domain: Are people able to choose?’, Journal of Public Economics, 91(3-4), pp. 701-22.

Van Rooij, M., Lusardi, A. and Alessie, R. (2011a). 'Financial literacy and stock market participation’, Journal of Financial Economics, vol. 101(2), pp. 449-72.

Van Rooij, M., Lusardi, A. and Alessie, R. (2011b), 'Financial literacy, retirement planning, and household wealth', Working Paper.

Venti, S. and Wise, D. (1998), 'The cause of wealth dispersion at retirement: Choice or chance?', American Economic Review, vol. 88(2), pp. 185-91.

Vissing-Jorgensen, A. (2004). 'Perspectives on behavioral finance: Does "irrationality" disappear with wealth? Evidence from expectations and actions', in: (M. Gertler and K. Rogoff, eds.), NBER Macroeconomics Annual 2003, pp. 139 - 208, Cambridge: MIT Press.

Yoong, J. (2011), 'Financial illiteracy and stock market participation: evidence from the RAND American Life Panel', in: (A. Lusardi and O. Mitchell, eds.), Financial Literacy: Implications for Retirement Security and the Financial Marketplace, Forthcoming Oxford University Press. 


\section{Appendix A. Summary statistics of explanatory variables and net worth}

Table A1. Summary statistics (mean) of explanatory variables

Weighted statistics

\begin{tabular}{|c|c|c|c|}
\hline Explanatory variable & Definition & $\begin{array}{l}\text { Whole } \\
\text { sample }\end{array}$ & $\begin{array}{l}\text { Final } \\
\text { e sample }\end{array}$ \\
\hline Age dummies & & & \\
\hline age $<=30$ & Respondent's age falls within mentioned age & 0.135 & 0.119 \\
\hline $30<$ age $<=40$ & category & 0.205 & 0.187 \\
\hline $40<$ age $<=50$ & & 0.191 & 0.195 \\
\hline $50<$ age $<=60$ & & 0.211 & 0.212 \\
\hline $60<$ age $<=70$ & & 0.148 & 0.160 \\
\hline age $>70$ & & 0.109 & 0.127 \\
\hline Education dummies & & & \\
\hline Lower intermediate and primary & Highest level of education completed by respondent & 0.306 & 0.324 \\
\hline Intermediate vocational & & 0.198 & 0.190 \\
\hline Secondary pre-university & & 0.152 & 0.151 \\
\hline Higher vocational & & 0.223 & 0.222 \\
\hline University & & 0.121 & 0.113 \\
\hline Male & Respondent is male & 0.515 & 0.531 \\
\hline Married & Respondent is married or cohabiting & 0.568 & 0.567 \\
\hline Number of children & Number of children living within household & 0.616 & 0.576 \\
\hline Retired & Respondent has retired & 0.184 & 0.204 \\
\hline Self-employed & Respondent is self-employed & 0.056 & 0.049 \\
\hline Household income & Net disposable household income (in $€ 1000$ ) & 24.6 & 23.8 \\
\hline High confidence in financial skills & Respondent is relatively overconfident & 0.286 & 0.288 \\
\hline Low confidence in financial skills & Respondent is relatively underconfident & 0.397 & 0.395 \\
\hline Risk aversion & & & \\
\hline Risk aversion 1 (completely disagree) & Based upon the following question: To what extent & 0.093 & 0.092 \\
\hline Risk aversion 2 & do you agree or disagree with the statement & 0.104 & 0.106 \\
\hline Risk aversion 3 & 'Investing in stocks is something I don't do, since it & 0.094 & 0.094 \\
\hline Risk aversion 4 & is too risky' (on a scale from 1 to 7 , where 1 means & 0.164 & 0.155 \\
\hline Risk aversion 5 & ‘completely disagree’ and 7 means ‘completely & 0.099 & 0.093 \\
\hline Risk aversion 6 & agree')? & 0.183 & 0.185 \\
\hline Risk aversion 7 (completely agree) & & 0.263 & 0.276 \\
\hline Smoking & Based upon the following two questions: 1) Do you & & \\
\hline No & smoke cigarettes at all? (yes, I smoke every now and & 0.735 & 0.748 \\
\hline Every now and then & then/yes, I smoke every day/no); and if smoke every & 0.055 & 0.055 \\
\hline Daily (<20 cigarettes) & day: 2) About how many cigarettes do you smoke a & 0.139 & 0.136 \\
\hline Daily ( $>=20$ cigarettes) & day? (less than 20 cigarettes/at least 20 cigarettes) & 0.071 & 0.062 \\
\hline Drinking (more than 4 glasses daily) & Respondent has more than 4 alcoholic drinks a day & 0.074 & 0.066 \\
\hline
\end{tabular}

Note: All variables are 0-1 dummy variables, except the number of children within the household and net household disposable income (thousands of euro). Whole (final) sample consists of 1508 (1091) households, except for variables which have been obtained from the annual DHS files.

Table A2. Total household net worth statistics

Thousands of euro

\section{Total net worth}

\begin{tabular}{|c|c|c|c|}
\hline Total net worth & Median & Mean & Standard deviation \\
\hline before trimming $(\mathrm{N}=1116)$ & 119.7 & 184.3 & 279.3 \\
\hline after trimming $(\mathrm{N}=1091)$ & 119.7 & 167.1 & 189.0 \\
\hline
\end{tabular}




\section{Appendix B. Wording of basic and advanced literacy questions}

\section{Basic financial literacy questions}

1) Suppose you had $€ 100$ in a savings account and the interest rate was $2 \%$ per year. After 5 years, how much do you think you would have in the account if you left the money to grow? (i) More than $€$ 102; (ii) Exactly $€ 102$; (iii) Less than $€ 102$; (iv) Do not know; (v) Refusal.

2) Suppose you had $€ 100$ in a savings account and the interest rate is $20 \%$ per year and you never withdraw money or interest payments. After 5 years, how much would you have on this account in total? (i) More than $€$ 200; (ii) Exactly $€$ 200; (iii) Less than $€$ 200; (iv) Do not know; (v) Refusal.

3) Imagine that the interest rate on your savings account was $1 \%$ per year and inflation was $2 \%$ per year. After 1 year, how much would you be able to buy with the money in this account? (i) More than today; (ii) Exactly the same; (iii) Less than today; (iv) Do not know; (v) Refusal.

4) Assume a friend inherits $€ 10000$ today and his sibling inherits $€ 100003$ years from now. Who is richer because of the inheritance? (i) My friend; (ii) His sibling; (iii) They are equally rich; (iv) Do not know; (v) Refusal.

5) Suppose that in the year 2010, your income has doubled and prices of all goods have doubled too. In 2010, how much will you be able to buy with your income? (i) More than today; (ii) The same; (iii) Less than today; (iv) Do not know; (v) Refusal.

\section{Advanced financial literacy questions}

6) Which statement describes the main function of the stock market?

(i) The stock market helps to predict stock earnings; (ii) The stock market results in an increase in the price of stocks; (iii)The stock market brings people who want to buy stocks together with those who want to sell stocks; (iv) None of the above; (v) Do not know; (vi) Refusal.

7) What happens if somebody buys the stock of firm B in the stock market? (i) He owns a part of firm B; (ii) He has let money to firm B; (iii) He is liable for firm B debt; (iv) None of the above; (v) Do not know; (vi) Refusal.

8) Which statement about mutual funds is correct? (i) Once one invests in a mutual fund, one cannot withdraw the money in the first year; (ii) Mutual funds can invest in several assets, for example invest in both stocks and bonds; (iii) Mutual funds pay a guaranteed rate of return which depends on their past performance; (iv) None of the above; (v) Do not know; (vi) Refusal.

9)What happens if somebody buys a bond of firm B?(i) He owns a part of firm B; (ii) He has lent money to firm B; (iii) He is liable for firm B's debts; (iv) None of the above; (v) Do not know; (vi) Refusal. 
10) Considering a long time period (for example 10 or 20 years), which asset normally gives the highest return: (i) Savings accounts; (ii) Bonds; (iii) Stocks; (iv) Do not know; (v) Refusal.

11) Normally, which asset displays the highest fluctuations over time: (i) Savings accounts; (ii) Bonds; (iii) Stocks; (iv) Do not know; (v) Refusal.

12) When an investor spreads his money among different assets, does the risk of losing money (i) Increase; (ii) Decrease; (iii) Stay the same; (iv) Do not know; (v) Refusal.

13) If you buy a 10-year bond, it means you cannot sell it after 5 years without incurring a major penalty. (i)True; (ii) False; (iii) Do not know; (iv) Refusal.

14) Stocks are normally riskier than bonds. (i) True; (ii) False; (iii) Do not know; (iv) Refusal.

15) Buying a company fund usually provides a safer return than a stock mutual fund. (i)True; (ii) False; (iii) Do not know; (iv) Refusal.

16) If the interest rate falls, what should happen to bond prices: (i) Rise; (ii) Fall; (iii) Stay the same; (iv) None of the above; (v) Do not know; (vi) Refusal. 


\section{Appendix C. Measuring literacy and confidence}

\section{Basic and advanced financial literacy}

The construction of the basic and advanced literacy indices is explained in detail in a previous paper (Van Rooij, Lusardi and Alessie, 2011a). In short, the basic literacy index is calculated from a factor analysis based on five simple questions. For each question, we created a dummy variable equal to one if the respondent provides the correct answer. The five questions measure numeracy and the understanding of economic concepts (related to the workings of inflation and interest rates) that are necessary in day-to-day transactions. The index of advanced literacy is based on eleven questions related to more advanced concepts such as the understanding of stocks and bonds, the relationship between risk and return, and the benefits of diversification. To account for the role of do not know answers, we created two dummies variables for each question, measuring whether the question is answered correctly and whether the respondent indicated that he or she did not know the answer, respectively. The procedure we used takes into account the fact that we have used minor variations in wording for three out of eleven questions to test the sensitivity of responses to these variations.

\section{Overconfidence and underconfidence}

At the beginning of our survey, we asked respondents to assess their own financial literacy. Table C1 reports the exact wording of the question and the distribution of responses. We grouped the bottom three categories and the top two categories from the 7-point response scale to have four categories of about equal size. We also divided the basic literacy index based on five simple economic questions over four different groups, and thereby tried to mimic the size of the self-reported literacy groups. This provides us with a relative ranking of self-reported literacy and one for measured basic literacy. Respondents who rank themselves higher than the rank we obtain for their basic literacy are labelled overconfident and those who rank themselves lower than the rank we obtain for their basic literacy are labelled underconfident. Both variables are binary dummies taking the value one if the respondent is overconfident or underconfident, respectively, and zero otherwise. In our sample, we have 404 overconfident respondents, 599 underconfident respondents, 464 respondents with an equal ranking for actual and self-reported literacy, and 41 respondents with missing information because they did not answer the self-assessed literacy question. The fact that we have many underconfident respondents is related to the fact that we are not able to match the group sizes exactly, since the top category for basic literacy is relatively large, containing 677 respondents (out of 1508) who answered all five questions correctly. 
Table C1. Self-assessed literacy

Number and percentage of respondents

How would you assess your understanding of economics (on a 7-point scale; 1 means very low and 7 means very high)?

\begin{tabular}{lrr}
\hline & $\mathrm{N}$ & $\%$ \\
\cline { 2 - 2 } 1 (very low) & 9 & \\
2 & 56 & 0.60 \\
3 & 137 & 3.71 \\
4 & 366 & 9.08 \\
5 & 499 & 24.27 \\
6 & 355 & 33.09 \\
7 (very high) & 45 & 23.54 \\
Do not know & 31 & 2.98 \\
Refusal & 10 & 2.06 \\
& & 0.66 \\
Total & 1508 & \\
& &
\end{tabular}


Table 1A. Basic financial literacy

Weighted percentages of total number of respondents $(\mathrm{N}=1508)$

\begin{tabular}{lllllll}
\hline & Numeracy & $\begin{array}{l}\text { Interest } \\
\text { compounding }\end{array}$ & Inflation & & $\begin{array}{l}\text { Time value } \\
\text { of money }\end{array}$ & $\begin{array}{l}\text { Money } \\
\text { illusion }\end{array}$ \\
\cline { 2 - 2 } Correct & 90.8 & 76.2 & 82.6 & & 72.3 & 71.8 \\
Incorrect & 5.2 & 19.6 & 8.6 & & 23.0 & 24.3 \\
Do not know & 3.7 & 3.8 & 8.5 & & 4.3 & 3.5 \\
\hline
\end{tabular}

Note: Correct, incorrect, and do not know responses do not sum up to $100 \%$ because of refusals. See Appendix B for the exact wording of the questions on basic financial literacy.

Table 1B. Basic literacy: Summary of responses

Weighted percentages of total number of respondents $(\mathrm{N}=1508)$

Number of correct, incorrect and do not know answers (out of five questions)

\begin{tabular}{|c|c|c|c|c|c|c|c|}
\hline & None & 1 & 2 & 3 & 4 & All & Mean \\
\hline Correct & 2.3 & 2.8 & 6.7 & 15.1 & 32.8 & 40.2 & 3.94 \\
\hline Incorrect & 45.2 & 35.7 & 13.6 & 4.4 & 1.1 & 0.0 & 0.81 \\
\hline Do not know & 88.9 & 5.9 & 1.7 & 1.4 & 0.7 & 1.5 & 0.24 \\
\hline
\end{tabular}

Note: Categories do not sum up to $100 \%$ because of rounding and means do not sum up to 5 due to refusals. 
Table 2A. Advanced financial literacy

Weighted percentages of total number of respondents $(\mathrm{N}=1508)$

\begin{tabular}{|c|c|c|c|}
\hline & Correct & Incorrect & DK \\
\hline Which statement describes the main function of the stock market? & 67.0 & 12.9 & 19.7 \\
\hline What happens if somebody buys the stock of firm B in the stock market? & 62.2 & 25.7 & 11.0 \\
\hline Which statement about mutual funds is correct? & 66.7 & 11.1 & 21.7 \\
\hline What happens if somebody buys a bond of firm B? & 55.6 & 17.8 & 26.4 \\
\hline $\begin{array}{l}\text { Considering a long time period (for example } 10 \text { or } 20 \text { years), which asset } \\
\text { normally gives the highest return: savings accounts, bonds or stocks? }\end{array}$ & 47.2 & 30.1 & 22.3 \\
\hline $\begin{array}{l}\text { Normally, which asset displays the highest fluctuations over time: savings } \\
\text { accounts, bonds or stocks? }\end{array}$ & 68.5 & 12.7 & 18.4 \\
\hline $\begin{array}{l}\text { When an investor spreads his money among different assets, does the risk } \\
\text { of losing money: increase, decrease or stay the same? }\end{array}$ & 63.3 & 17.4 & 19.0 \\
\hline $\begin{array}{l}\text { If you buy a } 10 \text {-year bond, it means you cannot sell it after } 5 \text { years } \\
\text { without incurring a major penalty. True or False? }\end{array}$ & 30.0 & 28.3 & 37.9 \\
\hline Stocks are normally riskier than bonds. True or False? ${ }^{1)}$ & 60.2 & 15.1 & 24.3 \\
\hline $\begin{array}{l}\text { Buying a company fund usually provides a safer return than a stock } \\
\text { mutual fund. True or False? }{ }^{1)}\end{array}$ & 48.2 & 24.8 & 26.6 \\
\hline $\begin{array}{l}\text { If the interest rate falls, what should happen to bond prices: rise, fall or } \\
\text { stay the same? }{ }^{1)}\end{array}$ & 24.6 & 37.1 & 37.5 \\
\hline
\end{tabular}

1) This question was phrased in two different ways. See Van Rooij, Lusardi and Alessie (2011a) for details. Note: DK = 'Do not know'; Correct, incorrect and DK responses do not sum up to $100 \%$ because of refusals. See Appendix B for the exact wording of the questions on advanced financial literacy.

Table 2B. Advanced literacy: Summary of responses

Weighted percentages of total number of respondents $(\mathrm{N}=1508)$

\begin{tabular}{|c|c|c|c|c|c|c|c|c|c|c|c|c|c|}
\hline & \multicolumn{13}{|c|}{ Number of correct, incorrect and do not know answers (out of eleven questions) } \\
\hline & None & 1 & 2 & 3 & 4 & 5 & 6 & 7 & 8 & 9 & 10 & All & Mean \\
\hline Correct & 7.6 & 5.1 & 5.2 & 6.4 & 7.3 & 10.0 & 11.1 & 11.3 & 10.8 & 10.6 & 9.8 & 5.0 & 5.93 \\
\hline Incorrect & 18.7 & 20.2 & 19.8 & 16.8 & 10.4 & 7.1 & 4.7 & 1.6 & 0.6 & 0.1 & 0.0 & 0.0 & 2.33 \\
\hline DK & 44.2 & 11.4 & 8.0 & 6.1 & 5.1 & 3.7 & 4.1 & 4.2 & 2.8 & 3.2 & 3.5 & 3.6 & 2.65 \\
\hline
\end{tabular}

Note: DK = 'Do not know’; Categories do not sum up to $100 \%$ because of rounding and means do not sum up to 11 due to refusals. 
Table 3. Total net worth and financial literacy

Thousands of euro ( $\mathrm{N}=1091)$

\begin{tabular}{|c|c|c|c|}
\hline \multirow[b]{2}{*}{ Basic literacy quartiles } & \multicolumn{3}{|c|}{ Total net worth } \\
\hline & Median & Mean & Standard deviation \\
\hline 1 (low) & 43.9 & 117.2 & 162.3 \\
\hline 2 & 98.8 & 150.2 & 164.7 \\
\hline 3 & 111.2 & 156.5 & 173.6 \\
\hline \multirow[t]{2}{*}{4 (high) } & 142.8 & 195.7 & 209.3 \\
\hline & \multicolumn{3}{|c|}{ Total net worth } \\
\hline Advanced literacy quartiles & Median & Mean & Standard deviation \\
\hline 1 (low) & 46.7 & 100.1 & 121.2 \\
\hline 2 & 82.0 & 129.3 & 151.0 \\
\hline 3 & 112.4 & 167.5 & 181.4 \\
\hline 4 (high) & 185.9 & 236.3 & 228.4 \\
\hline
\end{tabular}

Table 4. Asset ownership and financial literacy

Weighted percentages $(\mathrm{N}=1116)$

\begin{tabular}{|c|c|c|c|c|}
\hline \multirow[b]{2}{*}{ Basic literacy quartiles } & \multicolumn{4}{|c|}{ \% of households owning } \\
\hline & Stocks & Mutual funds & Bonds & Home \\
\hline 1 (low) & 2.4 & 5.6 & 1.9 & 40.5 \\
\hline 2 & 9.7 & 17.6 & 3.8 & 53.4 \\
\hline 3 & 10.2 & 16.5 & 3.0 & 54.4 \\
\hline \multirow[t]{2}{*}{4 (high) } & 18.1 & 23.9 & 6.1 & 60.8 \\
\hline & \multicolumn{4}{|c|}{$\%$ of households owning } \\
\hline Advanced literacy quartiles & Stocks & Mutual funds & Bonds & Home \\
\hline 1 (low) & 2.0 & 6.5 & 1.4 & 44.6 \\
\hline 2 & 5.0 & 11.8 & 1.2 & 44.8 \\
\hline 3 & 14.2 & 18.5 & 5.0 & 56.0 \\
\hline 4 (high) & 25.2 & 33.1 & 8.8 & 70.9 \\
\hline
\end{tabular}


Table 5A. Total net worth and financial literacy: multivariate regressions

\begin{tabular}{|c|c|c|c|c|c|c|}
\hline \multirow[b]{2}{*}{ Basic financial literacy index } & \multicolumn{2}{|l|}{$\begin{array}{c}(1) \\
\text { OLS }\end{array}$} & \multicolumn{2}{|l|}{$\begin{array}{c}(2) \\
\text { OLS }\end{array}$} & \multicolumn{2}{|l|}{$\begin{array}{c}(3) \\
\text { OLS }\end{array}$} \\
\hline & $12328 * * *$ & $(3.42)$ & $15804 * * *$ & (3.37) & $15712^{* * *}$ & $(3.08)$ \\
\hline Age dummy $(30<$ age< < =40) & $26904 * *$ & $(2.25)$ & $24581 * *$ & $(2.02)$ & 22398* & (1.69) \\
\hline Age dummy $(40<$ age $<=50)$ & $72269 * * *$ & $(5.42)$ & $72359 * * *$ & (5.34) & $74986 * * *$ & $(5.20)$ \\
\hline Age dummy $(50<$ age $<=60)$ & $131181 * * *$ & $(8.71)$ & $130456^{* * *}$ & (8.49) & $136511 * * *$ & (8.33) \\
\hline Age dummy $(60<$ age $<=70)$ & $143929 * * *$ & (7.01) & $144246 * * *$ & (6.94) & $152902 * * *$ & (7.25) \\
\hline Age dummy (age >70) & $166320 * * *$ & (6.31) & $161898 * * *$ & $(5.88)$ & $168605 * * *$ & $(6.15)$ \\
\hline Intermediate vocational education & 18230 & (1.37) & 12666 & $(0.93)$ & 12961 & $(0.92)$ \\
\hline Secondary pre-university education & 10709 & $(0.65)$ & 2851 & $(0.18)$ & 4714 & $(0.28)$ \\
\hline Higher vocational education & $25853 *$ & $(1.85)$ & 22434 & (1.59) & 18835 & $(1.30)$ \\
\hline University education & $37059 * *$ & (1.98) & $35853^{*}$ & (1.88) & 26112 & $(1.32)$ \\
\hline Male & -7952 & $(0.81)$ & -10204 & $(1.02)$ & $-20710 * *$ & $(1.97)$ \\
\hline Married & $30905^{* * *}$ & $(2.72)$ & $26639 * *$ & (2.29) & $24494 * *$ & $(2.08)$ \\
\hline Number of children & $10285 *$ & $(1.70)$ & $11166^{*}$ & (1.80) & 10199 & (1.59) \\
\hline Retired & $45437 * *$ & $(2.16)$ & $45454 * *$ & (2.11) & $42855 * *$ & (2.03) \\
\hline Self-employed & 26205 & (1.17) & 25016 & $(1.12)$ & 25300 & $(1.04)$ \\
\hline Ln(household income) & $-3277982 * * *$ & (3.76) & $-3261105 * * *$ & (3.72) & $-3062710 * * *$ & (3.69) \\
\hline $\operatorname{Ln}^{2}$ (household income) & $315864 * * *$ & (3.71) & $314721 * * *$ & (3.67) & $297871 * * *$ & (3.67) \\
\hline $\mathrm{Ln}^{3}$ (household income) & $-9676 * * *$ & (3.51) & $-9648 * * *$ & (3.45) & $-9179 * * *$ & (3.48) \\
\hline High confidence in financial skills & & & -10738 & $(0.79)$ & -9253 & $(0.66)$ \\
\hline Low confidence in financial skills & & & $-26368 * *$ & (2.15) & $-21614^{*}$ & $(1.70)$ \\
\hline Risk aversion dummy 2 (low) & & & & & -1181 & $(0.043)$ \\
\hline Risk aversion dummy 3 & & & & & -16204 & $(0.65)$ \\
\hline Risk aversion dummy 4 & & & & & -30789 & $(1.24)$ \\
\hline Risk aversion dummy 5 & & & & & -13917 & $(0.53)$ \\
\hline Risk aversion dummy 6 & & & & & $-55402 * *$ & $(2.41)$ \\
\hline Risk aversion dummy 7 (very high) & & & & & $-64013 * * *$ & $(2.85)$ \\
\hline Constant & $10880396 * * *$ & (3.67) & $10818615 * * *$ & (3.65) & $10088240 * * *$ & (3.58) \\
\hline Observations & 1091 & & 1060 & & 1013 & \\
\hline R-squared & 0.32 & & 0.32 & & 0.34 & \\
\hline $\mathrm{p}$-value test age $=0$ & 0.00 & & 0.00 & & 0.00 & \\
\hline $\mathrm{p}$-value test education $=0$ & 0.26 & & 0.27 & & 0.62 & \\
\hline $\mathrm{p}$-value test income $=0$ & 0.00 & & 0.00 & & 0.00 & \\
\hline p-value test confidence $=0$ & & & 0.10 & & 0.24 & \\
\hline $\mathrm{p}$-value test risk aversion $=0$ & & & & & 0.00 & \\
\hline
\end{tabular}

Note: Absolute value of robust $\mathrm{t}$-statistics in parentheses; ${ }^{* * *} \mathrm{p}<0.01,{ }^{* *} \mathrm{p}<0.05,{ }^{*} \mathrm{p}<0.1$. The dependent variable is net worth in thousands of euro. The most risk tolerant, non-smoking and moderately drinking ( 4 alcoholic drinks or less a day) respondents are the reference group. 
Table 5B. Total net worth and financial literacy: multivariate regressions

\begin{tabular}{|c|c|c|c|c|c|c|}
\hline \multirow[b]{2}{*}{ Advanced financial literacy index } & \multicolumn{2}{|l|}{$\begin{array}{c}(1) \\
\text { OLS }\end{array}$} & \multicolumn{2}{|c|}{$\begin{array}{l}(2) \\
\text { OLS }\end{array}$} & \multicolumn{2}{|c|}{$\begin{array}{l}\text { (3) } \\
\text { IV }\end{array}$} \\
\hline & & & $23514 * * *$ & $(4.86)$ & $67122 * *$ & $(2.28)$ \\
\hline Basic financial literacy index & $16694 * * *$ & (3.17) & 9050 & (1.64) & -5129 & $(0.45)$ \\
\hline Age dummy $(30<$ age< $<=40)$ & 20743 & $(1.55)$ & $24756^{*}$ & $(1.81)$ & $32198 * *$ & $(2.12)$ \\
\hline Age dummy $(40<$ age $<=50)$ & $76027 * * *$ & $(5.24)$ & $77806^{* * *}$ & $(5.31)$ & $81106^{* * *}$ & $(5.24)$ \\
\hline Age dummy $(50<$ age $<=60)$ & $136072 * * *$ & $(8.17)$ & $134470 * * *$ & $(8.05)$ & $131499 * * *$ & (7.49) \\
\hline Age dummy $(60<$ age $<=70)$ & $151976 * * *$ & (7.18) & $150595 * * *$ & (7.11) & $148034 * * *$ & $(6.71)$ \\
\hline Age dummy (age>70) & $169144 * * *$ & $(6.16)$ & $169701^{* * *}$ & (6.17) & $170733 * * *$ & (6.08) \\
\hline Intermediate vocational education & 16282 & $(1.14)$ & 12459 & $(0.87)$ & 5368 & $(0.35)$ \\
\hline Secondary pre-university education & 5994 & $(0.35)$ & -1197 & $(0.07)$ & -14533 & $(0.76)$ \\
\hline Higher vocational education & 17733 & $(1.21)$ & 11324 & $(0.77)$ & -563 & $(0.03)$ \\
\hline University education & 25821 & (1.30) & 16848 & $(0.84)$ & 208 & $(0.01)$ \\
\hline Male & $-19907 *$ & $(1.84)$ & $-26884 * *$ & $(2.49)$ & $-39823 * * *$ & $(3.01)$ \\
\hline Married & $22754 *$ & (1.89) & $24778 * *$ & $(2.07)$ & $28533 * *$ & $(2.28)$ \\
\hline Number of children & $10687 *$ & $(1.66)$ & $11424^{*}$ & (1.79) & $12790 * *$ & (1.99) \\
\hline Retired & $43503 * *$ & $(2.06)$ & $41651^{* *}$ & (1.98) & $38215^{*}$ & (1.78) \\
\hline Self-employed & 26025 & $(1.07)$ & 24797 & $(1.03)$ & 22520 & $(0.93)$ \\
\hline Ln(household income) & $-3066220 * * *$ & (3.68) & $-3011077 * * *$ & (3.57) & $-2908803^{* * *}$ & (3.28) \\
\hline $\operatorname{Ln}^{2}$ (household income) & $299340 * * *$ & (3.66) & $293782 * * *$ & (3.57) & $283474 * * *$ & (3.30) \\
\hline $\operatorname{Ln}^{3}$ (household income) & $-9261 * * *$ & (3.48) & $-9084 * * *$ & $(3.40)$ & $-8754 * * *$ & (3.17) \\
\hline High confidence in financial skills & -8685 & $(0.61)$ & -9829 & $(0.70)$ & -11951 & $(0.84)$ \\
\hline Low confidence in financial skills & $-23286 *$ & (1.83) & -19605 & $(1.55)$ & -12778 & $(0.94)$ \\
\hline Risk aversion dummy 2 (low) & -3888 & $(0.14)$ & -8001 & $(0.29)$ & -15629 & $(0.57)$ \\
\hline Risk aversion dummy 3 & -21340 & $(0.86)$ & -23968 & $(0.97)$ & -28841 & (1.17) \\
\hline Risk aversion dummy 4 & -35329 & $(1.41)$ & -33869 & $(1.36)$ & -31162 & (1.23) \\
\hline Risk aversion dummy 5 & -16025 & $(0.60)$ & -19345 & $(0.74)$ & -25502 & $(0.99)$ \\
\hline Risk aversion dummy 6 & $-57751 * *$ & $(2.51)$ & $-54037 * *$ & (2.37) & $-47149 * *$ & (1.98) \\
\hline Risk aversion dummy 7 (very high) & $-66105^{* * *}$ & (2.93) & $-60545 * * *$ & $(2.71)$ & $-50234 * *$ & $(2.07)$ \\
\hline Smoking: every now and then & -20230 & $(1.22)$ & -18589 & $(1.15)$ & -15544 & $(0.95)$ \\
\hline Smoking: daily ( $<20$ cigarettes) & -6861 & $(0.39)$ & -5978 & $(0.34)$ & -4339 & $(0.25)$ \\
\hline Smoking: daily ( $>=20$ cigarettes) & -20227 & $(0.73)$ & -21097 & $(0.76)$ & -22711 & $(0.82)$ \\
\hline Drinking: daily (> 4 drinks) & -966 & $(0.04)$ & -1802 & $(0.08)$ & -3353 & $(0.15)$ \\
\hline Constant & $10066777 * * *$ & $(3.56)$ & $9897789 * * *$ & (3.45) & $9584366 * * *$ & (3.15) \\
\hline Observations & 1003 & & 1003 & & 1003 & \\
\hline R-squared & 0.34 & & 0.35 & & 0.32 & \\
\hline $\mathrm{p}$-value test age $=0$ & 0.00 & & 0.00 & & 0.00 & \\
\hline $\mathrm{p}$-value test education $=0$ & 0.64 & & 0.81 & & 0.84 & \\
\hline $\mathrm{p}$-value test income $=0$ & 0.00 & & 0.00 & & 0.00 & \\
\hline $\mathrm{p}$-value test confidence $=0$ & 0.18 & & 0.30 & & 0.56 & \\
\hline $\mathrm{p}$-value test risk aversion $=0$ & 0.00 & & 0.01 & & 0.48 & \\
\hline $\mathrm{p}$-value test smoking, drinking $=0$ & 0.74 & & 0.77 & & 0.83 & \\
\hline F-statistic first stage regression & & & & & 13.0 & \\
\hline p-value exogeneity test & & & & & 0.18 & \\
\hline
\end{tabular}

Note: Absolute value of robust t-statistics in parentheses; $* * * \mathrm{p}<0.01, * * \mathrm{p}<0.05, * \mathrm{p}<0.1$. The dependent variable is net worth in thousands of euro. The most risk tolerant, non-smoking and moderately drinking (4 alcoholic drinks or less a day) respondents are the reference group. The advanced literacy index has been instrumented using dummy variables indicating how much the respondent's education was devoted to economics. The reference group in this case consists of those respondents whose education was devoted a lot to economics. 
Table 6. Retirement planning across demographics Weighted household percentages

\begin{tabular}{|c|c|c|c|c|}
\hline \multirow[b]{2}{*}{ Education } & \multicolumn{3}{|c|}{ Percentage of planners } & \multirow[b]{2}{*}{$\mathrm{N}$} \\
\hline & Simple & Serious & Successful & \\
\hline Primary & 20.6 & 16.9 & 15.9 & 67 \\
\hline Preparatory intermediate voc. & 37.3 & 27.6 & 25.1 & 345 \\
\hline Intermediate vocational & 33.0 & 26.2 & 22.7 & 295 \\
\hline Secondary pre-university & 33.1 & 26.6 & 23.1 & 207 \\
\hline Higher vocational & 35.5 & 30.8 & 29.1 & 397 \\
\hline University & 39.8 & 29.9 & 28.9 & 197 \\
\hline Pearson chi2(5) & 9.50 & 3.37 & 4.75 & \\
\hline p-value & 0.09 & 0.64 & 0.45 & \\
\hline Age & Simple & Serious & Successful & $\mathrm{N}$ \\
\hline 21-30 years & 24.8 & 18.5 & 14.9 & 179 \\
\hline 31-40 years & 30.0 & 23.0 & 21.8 & 306 \\
\hline $41-50$ years & 34.6 & 27.1 & 24.8 & 333 \\
\hline 51-60 years & 45.4 & 36.7 & 34.0 & 311 \\
\hline $61-70$ years & 34.8 & 28.4 & 25.3 & 217 \\
\hline 71 years and older & 34.4 & 28.9 & 27.0 & 162 \\
\hline Pearson chi2(5) & 23.4 & 19.7 & 19.8 & \\
\hline p-value & 0.00 & 0.00 & 0.00 & \\
\hline Gender & Simple & Serious & Successful & $\mathrm{N}$ \\
\hline Female & 32.6 & 26.5 & 24.4 & 674 \\
\hline Male & 36.6 & 28.4 & 25.7 & 834 \\
\hline Pearson chi2(1) & 0.42 & 0.03 & 0.02 & \\
\hline p-value & 0.52 & 0.86 & 0.88 & \\
\hline Marital status & Simple & Serious & Successful & $\mathrm{N}$ \\
\hline Single/divorced/widow & 0.323 & 0.237 & 0.213 & \\
\hline Married/living together & 0.364 & 0.304 & 0.279 & $\begin{array}{l}476 \\
1032\end{array}$ \\
\hline Pearson chi2(1) & 1.59 & 3.35 & 4.04 & \\
\hline p-value & 0.21 & 0.07 & 0.04 & \\
\hline
\end{tabular}

Note: Percentages may not sum up to 100 due to rounding. 
Table 7. Retirement planning and financial literacy: some simple statistics Weighted household percentages

\begin{tabular}{|c|c|c|c|c|}
\hline \multirow[b]{2}{*}{ Basic literacy } & \multicolumn{3}{|c|}{ Percentage of planners } & \multirow[b]{2}{*}{$\mathrm{N}$} \\
\hline & Simple & Serious & Successful & \\
\hline 1 (low) & 31.9 & 23.8 & 21.7 & 217 \\
\hline 2 & 33.7 & 27.9 & 22.9 & 284 \\
\hline 3 & 31.4 & 26.4 & 24.0 & 350 \\
\hline 4 (high) & 38.1 & 29.5 & 28.2 & 657 \\
\hline Pearson chi2(3) & 1.95 & 0.94 & 3.62 & \\
\hline p-value & 0.58 & 0.82 & 0.31 & \\
\hline Advanced literacy & Simple & Serious & Successful & $\mathrm{N}$ \\
\hline 1 (low) & 24.5 & 19.9 & 18.6 & 330 \\
\hline 2 & 31.8 & 22.9 & 20.9 & 354 \\
\hline 3 & 38.2 & 31.7 & 28.3 & 371 \\
\hline 4 (high) & 44.1 & 35.5 & 32.5 & 453 \\
\hline Pearson chi2(3) & 32.6 & 22.9 & 20.6 & \\
\hline p-value & 0.00 & 0.00 & 0.00 & \\
\hline Self-assessed literacy & Simple & Serious & Successful & $\mathrm{N}$ \\
\hline 1 (very low) & 53.4 & 44.1 & 44.1 & 9 \\
\hline 2 & 33.3 & 17.8 & 15.0 & 56 \\
\hline 3 & 21.2 & 17.3 & 16.2 & 137 \\
\hline 4 & 26.7 & 20.3 & 16.1 & 366 \\
\hline 5 & 37.0 & 30.7 & 28.2 & 499 \\
\hline 6 & 45.7 & 37.7 & 36.1 & 355 \\
\hline 7 (very high) & 51.4 & 42.7 & 41.5 & 45 \\
\hline Do not know & 17.6 & 10.2 & 10.2 & 31 \\
\hline Refusal & 27.2 & 13.9 & 13.9 & 10 \\
\hline Pearson chi2(8) & 48.6 & 43.6 & 49.9 & \\
\hline p-value & 0.00 & 0.00 & 0.00 & \\
\hline
\end{tabular}

Note: Percentages may not sum up to 100 due to rounding. 
Table 8. Retirement planning and financial literacy: multivariate regressions

\begin{tabular}{|c|c|c|c|c|}
\hline \multirow[b]{2}{*}{ Advanced financial literacy index } & \multicolumn{2}{|c|}{ OLS } & \multicolumn{2}{|c|}{ IV } \\
\hline & $0.072 * * *$ & $(4.13)$ & $0.25 * * *$ & $(2.66)$ \\
\hline Basic financial literacy index & $0.031 *$ & $(1.79)$ & -0.026 & $(0.71)$ \\
\hline Age dummy $(30<$ age $<=40)$ & 0.026 & $(0.43)$ & 0.056 & $(0.89)$ \\
\hline Age dummy $(40<$ age $<=50)$ & 0.084 & (1.39) & 0.097 & $(1.62)$ \\
\hline Age dummy $(50<$ age $<=60)$ & $0.18^{* * *}$ & (2.99) & $0.17 * * *$ & $(2.77)$ \\
\hline Age dummy $(60<$ age $<=70)$ & $0.16^{* *}$ & $(2.16)$ & $0.15^{* *}$ & $(2.04)$ \\
\hline Age dummy (age>70) & 0.052 & $(0.62)$ & 0.056 & $(0.69)$ \\
\hline Intermediate vocational education & 0.0029 & $(0.06)$ & -0.026 & $(0.49)$ \\
\hline Secondary pre-university education & -0.0081 & $(0.15)$ & -0.062 & $(1.02)$ \\
\hline Higher vocational education & -0.033 & $(0.74)$ & -0.080 & $(1.57)$ \\
\hline University education & 0.073 & $(1.31)$ & 0.0064 & $(0.10)$ \\
\hline Male & $-0.061^{*}$ & $(1.79)$ & $-0.11^{* *}$ & $(2.55)$ \\
\hline Married & -0.032 & $(0.87)$ & -0.017 & $(0.44)$ \\
\hline Number of children & 0.017 & $(0.92)$ & 0.022 & $(1.20)$ \\
\hline Retired & 0.034 & $(0.54)$ & 0.020 & $(0.32)$ \\
\hline Self-employed & 0.0090 & $(0.13)$ & -0.000095 & $(0.00)$ \\
\hline Ln(household income) & -0.13 & $(0.05)$ & 0.28 & $(0.09)$ \\
\hline $\operatorname{Ln}^{2}$ (household income) & 0.029 & $(0.12)$ & -0.012 & $(0.04)$ \\
\hline $\operatorname{Ln}^{3}$ (household income) & -0.0013 & $(0.16)$ & 0.000004 & $(0.00)$ \\
\hline High confidence in financial skills & $0.14^{* * *}$ & (3.35) & $0.13 * * *$ & $(2.98)$ \\
\hline Low confidence in financial skills & -0.048 & $(1.30)$ & -0.021 & $(0.51)$ \\
\hline Risk aversion dummy 2 (low) & 0.0085 & $(0.13)$ & -0.022 & $(0.32)$ \\
\hline Risk aversion dummy 3 & 0.023 & $(0.34)$ & 0.0034 & $(0.05)$ \\
\hline Risk aversion dummy 4 & 0.017 & $(0.27)$ & 0.028 & $(0.43)$ \\
\hline Risk aversion dummy 5 & 0.017 & $(0.24)$ & -0.0078 & $(0.11)$ \\
\hline Risk aversion dummy 6 & -0.052 & $(0.85)$ & -0.025 & $(0.38)$ \\
\hline Risk aversion dummy 7 (very high) & -0.010 & $(0.17)$ & 0.031 & $(0.48)$ \\
\hline Smoking: now and then & -0.046 & $(0.69)$ & -0.034 & $(0.48)$ \\
\hline Smoking: daily (1-20 cigarettes) & 0.0100 & $(0.20)$ & 0.017 & $(0.33)$ \\
\hline Smoking: daily (> 20cigarettes) & -0.096 & $(1.30)$ & -0.10 & $(1.28)$ \\
\hline Drinking: daily (> 4 glasses) & -0.024 & $(0.37)$ & -0.030 & $(0.46)$ \\
\hline Constant & 0.061 & $(0.01)$ & -1.20 & $(0.11)$ \\
\hline Observations & 1003 & & 1003 & \\
\hline R-squared & 0.07 & & -0.01 & \\
\hline $\mathrm{p}$-value test age $=0$ & 0.01 & & 0.06 & \\
\hline $\mathrm{p}$-value test education $=0$ & 0.38 & & 0.32 & \\
\hline $\mathrm{p}$-value test income $=0$ & 0.46 & & 0.78 & \\
\hline $\mathrm{p}$-value test confidence $=0$ & 0.00 & & 0.00 & \\
\hline $\mathrm{p}$-value test risk aversion $=0$ & 0.84 & & 0.93 & \\
\hline $\mathrm{p}$-value test smoking, drinking $=0$ & 0.68 & & 0.71 & \\
\hline F-statistic first stage regression & & & 13.0 & \\
\hline p-value exogeneity test & & & 0.06 & \\
\hline
\end{tabular}

Note: Absolute value of robust t-statistics in parentheses; *** $\mathrm{p}<0.01, * * \mathrm{p}<0.05, * \mathrm{p}<0.1$. The dependent variable is a 0-1 dummy indicating whether respondents have tried to calculate saving needs for retirement. The most risk tolerant, non-smoking and moderately drinking (4 alcoholic drinks or less a day) respondents are the reference group. The advanced literacy index has been instrumented using dummy variables indicating how much the respondent's education was devoted to economics. The reference group in this case consists of those respondents whose education was devoted a lot to economics. 


\section{CFS Working Paper Series:}

\begin{tabular}{|c|c|c|}
\hline No. & Author(s) & Title \\
\hline $2011 / 20$ & Marcel Bluhm & $\begin{array}{l}\text { Investigating the Monetary Policy of Central } \\
\text { Banks with Assessment Indicators }\end{array}$ \\
\hline 2011/19 & $\begin{array}{l}\text { Marcel Bluhm } \\
\text { Jan Pieter Krahnen }\end{array}$ & $\begin{array}{l}\text { Default Risk in an Interconnected Banking } \\
\text { System with Endogeneous Asset Markets }\end{array}$ \\
\hline 2011/18 & $\begin{array}{l}\text { Kristian Rydqvist } \\
\text { Joshua Spizman } \\
\text { Ilya Strebulaev }\end{array}$ & The Evolution of Aggregate Stock Ownership \\
\hline 2011/17 & $\begin{array}{l}\text { Azi Ben-Rephael } \\
\text { Jacob Oded } \\
\text { Avi Wohl }\end{array}$ & $\begin{array}{l}\text { Do Firms Buy Their Stock at Bargain Prices? } \\
\text { Evidence from Actual Stock Repurchase } \\
\text { Disclosure }\end{array}$ \\
\hline 2011/16 & $\begin{array}{l}\text { Christian Andres } \\
\text { André Betzer } \\
\text { Marc Goergen }\end{array}$ & $\begin{array}{l}\text { Dividend Policy, Corporate Control and Tax } \\
\text { Clienteles. The Case of Germany }\end{array}$ \\
\hline 2011/15 & Christopher D. Carroll & $\begin{array}{l}\text { Theoretical Foundations of Buffer Stock } \\
\text { Saving }\end{array}$ \\
\hline 2011/14 & Laura Moretti & $\begin{array}{l}\text { Transparency and Emerging Market Bond } \\
\text { Spreads }\end{array}$ \\
\hline $2011 / 13$ & Otmar Issing & $\begin{array}{l}\text { Lessons for Monetary Policy: What Should the } \\
\text { Consensus Be? }\end{array}$ \\
\hline 2011/12 & Charles Goodhart & $\begin{array}{l}\text { The Emerging New Architecture of Financial } \\
\text { Regulation }\end{array}$ \\
\hline 2011/11 & $\begin{array}{l}\text { Xavier Freixas } \\
\text { Christian Laux }\end{array}$ & $\begin{array}{l}\text { Disclosure, Transparency, and Market } \\
\text { Discipline }\end{array}$ \\
\hline 2011/10 & $\begin{array}{l}\text { Reint Gropp } \\
\text { Christian Hirsch } \\
\text { Jan P. Krahnen }\end{array}$ & $\begin{array}{l}\text { Is Rated Debt Arm's Length? Evidence from } \\
\text { Mergers and Acquisitions }\end{array}$ \\
\hline
\end{tabular}

Copies of working papers can be downloaded at http://www.ifk-cfs.de 